\title{
EFFECT OF TILLAGE AND ANHYDROUS AMMONIA APPLICATION ON NITROGEN USE EFFICIENCY OF HARD RED WINTER WHEAT
}

\section{By}

\section{ROGER KEITH TEAL}

\author{
Bachelor of Science \\ University of Tennessee at Martin \\ Martin, Tennessee \\ 2000
Submitted to the Faculty of the
Graduate College of the
Oklahoma State University
in partial fulfillment of the requirements for the Degree of MASTER OF SCIENCE
December, 2002




\section{EFFECT OF TILLAGE AND ANHYDROUS AMMONIA}

\section{APPLICATION ON NITROGEN USE EFFICIENCY dedication to OF HARD RED WINTER WHEAT

Thesis Approved:
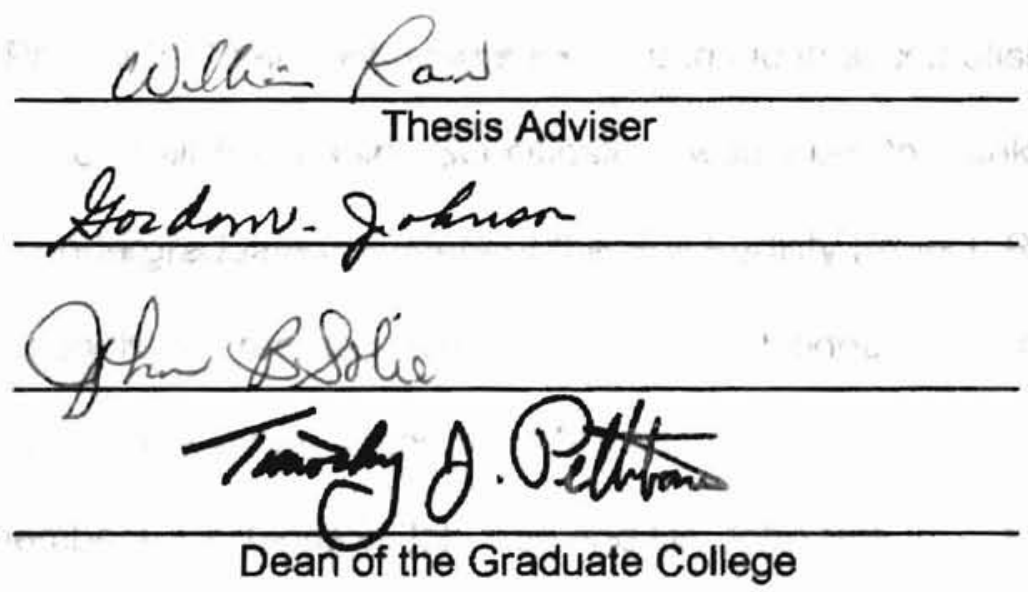


\section{ACKNOWLEDGEMENTS}

First of all I would like to thank God for giving me the strength and dedication to complete this degree, fore without His love and patience this work would not have been possible. I am also very grateful to my family, who's support and encouragement made my efforts much more effective to this research. I would also like to think the Department of Plant and Soil Sciences for the opportunity to work and study at Oklahoma State University. I would especially like to thank the Soil Fertility Project for their continued support and aid in accomplishing my goals and most of all for their friendship. Specifically, I would like to thank the following graduate and undergraduate members of the Soil Fertility Project: Robert Mullen, Wade Thomason, Kyle Freeman, Kathie Wynn, Paul Hodgen, Micah Humphreys, Aaron Witt, Keri Brixey, Chad Miller, Kent Martin, and Angie Harting. To my committee members, Dr. Gordon Johnson and Dr. John Solie, I thank you for your assistance and guidance throughout my pursuit of this degree. Finaliy, but certainly not least, I would like to thank my major adviser Dr. Bill Raun for: allowing me to be a part of the project, an incredible amount of patience, and the chance to make a difference. 


\section{TABLE OF CONTENTS}

Chapter

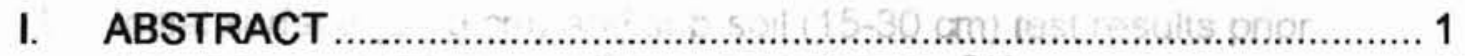

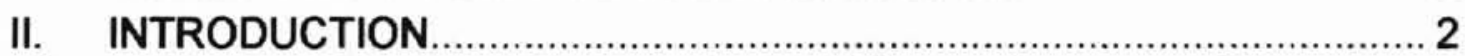

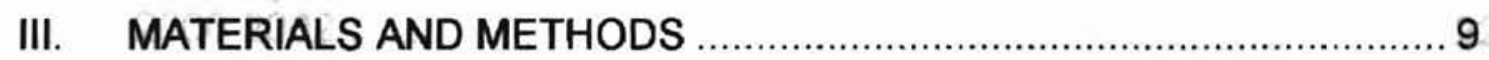

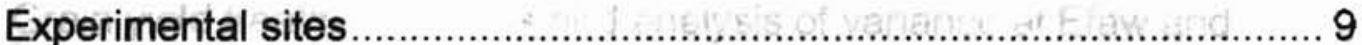

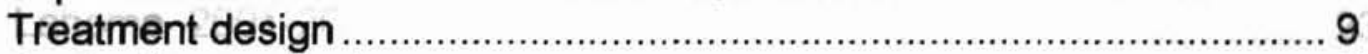

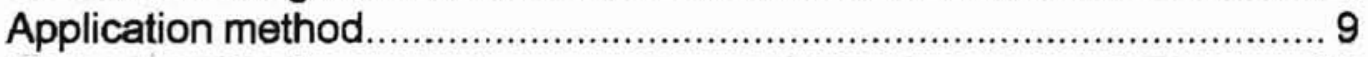

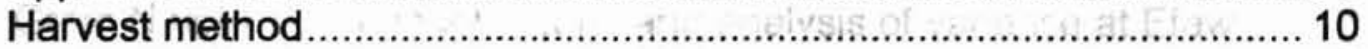

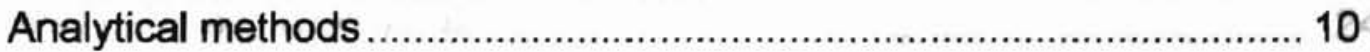

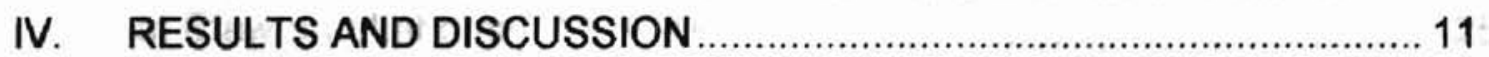

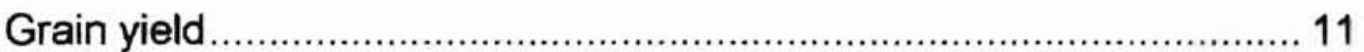

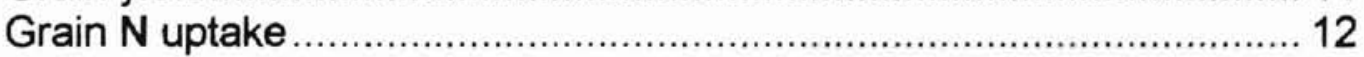

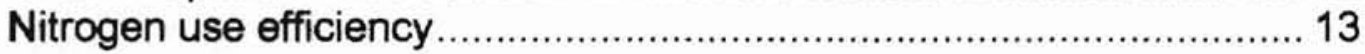

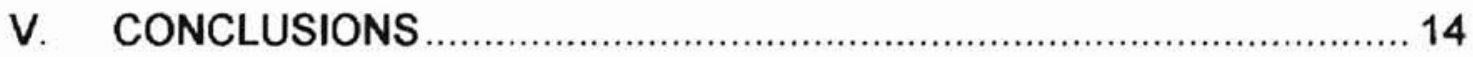

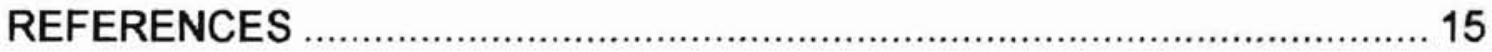

APPENDIX 


\section{LIST OF TABLES}

Table

1. Initial surface $(0-15 \mathrm{~cm})$ and sub-soil $(15-30 \mathrm{~cm})$ test results prior to experiment initiation at Efaw and Lahoma, OK

2. Planting, fertilizer, and harvest dates at Efaw and Lahoma, OK, 2000-2002.

3. Grain yield treatment means and analysis of variance at Efaw and Lahoma, 2001-2002.

4. Grain $\mathbf{N}$ uptake treatment means and analysis of variance at Efaw and Lahoma, 2001-2002.

5. Nitrogen Use Efficiency treatment means and analysis of variance at Efaw and Lahoma, 2001-2002 


\title{
EFFECT OF TILLAGE AND ANHYDROUS AMMONIA APPLICATION ON NITROGEN USE EFFEICIENCY OF HARD RED WINTER WHEAT
}

\begin{abstract}
Nitrogen use efficiency (NUE) is estimated to be $33 \%$ throughout the
\end{abstract} world, and can be lower when $\mathbf{N}$ is applied in single, pre-plant applications compared with split $\mathrm{N}$ applications. This study was conducted to evaluate tillage system and anhydrous ammonia application methods on yield, $\mathrm{N}$ uptake, and NUE in hard red winter wheat (Triticum aestivum L.), using a narrow $(10 \mathrm{~cm})$ nozzle spacing on a V-blade (Noble or sweep blade) applicator and wide (46 cm) nozzle spacing on a knife applicator. At Stillwater (Efaw) no significant differences between no-till and conventional-till treatments in grain yield were observed the initial year, however conventional tillage did obtain a significant advantage the second year. Grain $\mathbf{N}$ uptake was increased in conventional-till in consecutive years at Efaw, but no advantage occurred in NUE from either tillage system in either year. At Lahoma conventional tillage increased grain yield and grain $\mathrm{N}$ uptake in consecutive years compared to no-till. Conversely, no-till had a significant advantage for NUE both years. Based on two years of data, no-till when compared to conventional-till could be advantageous, and improve NUE. A trend for improved grain yield, grain $\mathrm{N}$ uptake, and NUE was noted for application 
of anhydrous ammonia with a narrow nozzle spacing V-blade applicator over the more popular wider nozzle spacing knife applicator in conventional-till, but the trend was reversed with the knife applicator increasing grain yield, grain $\mathbf{N}$ uptake, and NUE over the V-blade applicator in no-till.

\section{INTRODUCTION}

Soil erosion has been a major concern since the beginning of agriculture, but it was not until the Great Dust Bowl of the 1930s that the problem received worldwide attention. With so many deaths caused by black pneumonia and total crop destruction by wind-borne soil in massive volumes, measures were taken to make sure that this would never happen again. Among those new practices was zero tillage. Zero tillage has been used as a means of annual crop production in most parts of the country for well over thirty years, but not in the Southern Great Plains. Anhydrous Ammonia (AA) as a nitrogen fertilizer source is very popular in winter wheat (Triticum aestivum L.) production in Oklahoma because of lower cost compared to other nitrogen fertilizers. Limited published research has been completed to show the effects of $A A$ in winter wheat production in this area. This study was conducted to determine if tillage and AA application methods affect nitrogen use efficiency (NUE) of winter wheat in Oklahoma.

No-till was originally used as a method to stop soil erosion. Researchers found that planting crops in previous crop stubble greatly reduced the amount of soil removed by water and wind erosion. McGregor et al. (1992) reported that during a 5-year period (1987 through 1991), no-till soybean yielded $44 \%$ more 
than conventional-till yields. Intensive tillage has led to annual sediment discharge of $15.9 \mathrm{Mg} \mathrm{ha}^{-1}$ in the southern Great Plains (Smith et al., 1991).) McGregor et al. (1992) reports indicated increasing soil losses with time under conventional-till and decreasing soilloses with time for no-till. This study conducted over 14 years; noted no-till yields exceeded those of conventional-till yields by $800 \mathrm{~kg}^{\prime} \mathrm{ha} \mathrm{yr}^{-1}$ (McGregor et al., 1999). No-till reduced runoff 1 to $35 \%$ over conventional-till and reduced soil loss by 23 to $77 \%$ compared to conventional-till (McGregor et al., 1999). King et al., (1995), Mclsaac et al., (1990), Pesant et al., (1987) and Lembi et al., (1985), similarly found that longterm no-till practices are effective and practical in reducing rill erodibility and sediment loss. Brenneman and Laflen (1982) and Cogo et al. (1984) concluded that residue cover reduces erosion in one of four ways: 1) dissipation of the energy from raindrop impact: 2) slowing runoff, and increasing flow depth, which in turn reduces the impact of raindrops: 3 ) absorption of some of the forces from runoff that are usually applied to the soil surface: and 4) creation of small reservoirs of ponded runoff causing deposition.

There have been several other unforeseen advantages of no-till over conventional-till that researchers have discovered over time. Edwards et al., (1990) found that no-till improved soil drainage, while Weersink et al., (1992) stated that no-till reduces labor costs. Aase and Pikul (1995) found that in annual spring wheat production, no-till was the most efficient crop and soil management practice from the standpoint of yield, water use efficiency, soil organic C, and bulk density. However, Mielke et al. (1986), Bruce et al. (1990), 
Rhoton et al: (1993), and Vyn and Raimbault (1993) have reported that bulk density increases under no-till versus conventional-till.-Blevins et al. (1983), Unger (1991), and Ismail et al: (1994) reported that tillage had no effect on bulk density. Alternatively, Lal et al. (1994), Pikul and Aase, (1995), and Dao (1993) agreed with Aase and Pikul (1995) reporting that no-till reduced bulk density. After looking at these studies in great detail, it can be concluded that no-till can increase bulk density of soils by increasing soil compaction in saturated claytextured soils, but in dry clay-textured soils as well as silt and sandy soils of any saturation level, bulk density will decrease with no-till compared to conventionaltill. There have been other controversies comparing no-till to conventional-till systems as well as bulk density, one such argument being $\mathrm{pH}$. Blevins et al. (1977) and Dick (1983) found that $\mathrm{pH}$ decreased under no-till as compared to conventional-till as nitrogen rates were increased, but Lal et al. (1994) found no effect of tillage on $\mathrm{pH}$.

Research has indicated that soil organic matter content is related to amount of residue returned to the soil (Black, 1973: Campbell and Zentner, 1993; Eghball et al., 1994; Christensen et al., 1994). In the semiarid regions where dryland wheat is grown, soil organic carbon (C) and nitrogen $(\mathrm{N})$ has declined with years of cultivation (Dodge and Jones, 1948; Haas et al., 1957; Hobbs and Brown, 1957; Young et al., 1960). This loss of soil organic $\mathrm{C}$ and $\mathrm{N}$ in the Great Plains has been caused by the use of tillage and summer fallow, which have accelerated organic matter decomposition rates and erosion (Ridley and Hedlin, 1968; Haas et al., 1957). Ismail et al. (1994), Lal et al. (1994), Christensen et al. 
(1994), Unger (1991), and Wood et al: (1991) reported soil organic matter was greater under no-till and increased with time in some instances. Lamb et al. (1985) and Bauer and Black (1981) agreed with long-term studies where virgin soils were put under cultivation, losses of soil organic $\mathrm{C}$ and $\mathrm{N}$ were much higher for conventional-till than no-till systems Allison (1973) found that most nonlegume crops acquire 30 to $100 \%$ of their $\mathrm{N}$ nutritional needs from soil organic matter. Bauer and Black (1994) discovered that $1 \mathrm{Mg} \mathrm{ha}^{-1}$ of soil organic matter contributed the equivalent of $15.6 \mathrm{~kg} \mathrm{ha}^{-1}$ of wheat grain yield. Doran (1980), Follett and Schimel (1989), Bakersman and deWit (1970) and Groffman, (1984) have reported that microbial activity is generally greater in the first few centimeters of soil under no-till as compared to conventional-till, resulting in reduced organic matter levels in conventional-till as compared to no-till systems. Tillage significantly reduces the diversity of bacteria by reducing both substrate richness and evenness (Lupwayi et al., 1998). Further comparisons showed that no-till enhanced $\mathbf{N}$ immobilization and reduced nitrification rates when compared to conventional-till (Doran, 1980; Stinner et al., 1983), often resulting in less nitrate leaching (Elliott et al., 1986; Lamb et al., 1985) and leaving less nitrate in the soil profile (Fenster and Peterson, 1979; Dowdell and Cannell, 1975). Although there are lower nitrate levels in soil profiles in no-till systems, studies have shown that nitrate has been found deeper in the profiles of no-till soils (Eck and Jones, 1992).

The results of a 10-year study have shown that $\mathrm{N}$-mineralization rates were higher in annual cropping systems under no-till, than under conventional-till 
(Wienhold and Halvorson, 1999). This increased mineralization is caused by increased $\mathrm{N}$ stored as labile organic forms. Increased amounts of organic $\mathrm{N}$ will supply more nitrogen to crops, which will result in less $\mathrm{N}$ required from fertilizers as well as reduced leaching. Wienhold and Halvorson (1999) also believe that higher $\mathbf{N}$ rates will increase immobilization because of the increased plant residue resulting from the higher $\mathrm{N}$ rates increasing the $\mathrm{C} / \mathrm{N}$ ratio of the residue. Several other studies have shown that immobilization was higher at lower applied $\mathrm{N}$ rates and crop $\mathrm{N}$ uptake was less with no-till systems (Kitur et al., 1984; Smith and Sharpley, 1990; Wagger et al., 1985; Black and Reitz, 1972; Cochran et al., 1980; Elliot et al., 1986; Dowdell and Crees, 1980; Knowles et al., 1993; Rice and Smith, 1984). This research has also found evidence that immobilization of surface applied $\mathbf{N}$ fertilizers accounts for most of the differences in $\mathbf{N}$ response between no-till and conventional-till systems. Their research also shows that notill systems required more $\mathbf{N}$ fertilizer when surface applied at lower rates. However, Fox and Bandel (1986) discovered that no-till increased mineralization compared to conventional-till during the latter part of the growing season. Rice and Smith (1982) and Rodriguez and Giambiagi (1995) found that no-till enhances denitrification, because of the increase in soil water supply commonly occurring in no-till, reducing the amount aerobic activity in the soil. There are some conflicting views between Wienhold and Halvorson (1999) and the others stated above, but keep in mind that the Wienhold and Halvorson (1999) study was long-term (10 years), while the others were short-term (5 years or less). Wienhold and Halvorson were the only ones to account for the build up of soil 
organic matter $(\mathrm{OM})$, and it would not be possible for soil OM to be a major factor in a short-term study.

Water use efficiency (WUE) is probably the most important advantage to no-till systems over conventional-till. Bonfil et al. (1999) found that no-till management over a 5-year study increased yields 62 to $67 \%$ in wheat-fallow rotations and 18 to $75 \%$ in continuous wheat over conventional-till in semiarid regions of Israel. Cantero-Martinez et al. (1999), Peterson et al. (1996), and Kolberg et al. (1996) all found similar results in Australia and the Great Plains of the United States. No-till increases WUE by reducing evaporation, increasing water infiltration, improving soil structure, which in turn enhances root development (Aase and Pikul, 1995; Holland and Felton, 1989; Jones and Popham, 1997; Norwood, 1994; Smika and Unger, 1986; Waddell and Weil, 1996; Kirkegaard et al., 1995; Merrill et al., 1996; Dao, 1993; Lopez-Bellido et al., 1996). Winter wheat is now being produced successfully and out-yielding spring wheat in the Northern Great Plains of the United States and Canada without requiring a fallow period, when no-till is used with adequate $\mathrm{N}$ fertilization (Halvorson et al., 1999; Entz and Fowler, 1991). By increasing stored water in the soil, no-till has reduced the detrimental effects of climate variability on annual winter wheat production (Dao, 1993).

Studies have shown that deep placement of $\mathrm{N}$ can minimize volatilization or immobilization losses. Placement of $\mathbf{N}$ is a major factor of $\mathbf{N}$ utilization and a $20 \%$ increase in NUE has been observed with band placement, compared to surface broadcast (Soper et al., 1971; Toews and Soper, 1978; Tomar and 
Soper, 1981). They found that $\mathrm{N}$ immobilization and increased $\mathrm{N}$ uptake could be achieved by reducing fertilizer contact with the surface residue. Rao and Dao (1996) found that final grain yield and grain $\mathrm{N}$ content were not affected by $\mathrm{N}$ placement in plowed plots. No-till improved grain yield by $32 \%$ for a below the seed row (BL) application and 15\% for between the rows (BT) application. Grain $\mathrm{N}$ content was increased by $33 \%$ for BL and $25 \%$ for BT as compared to a surface broadcast application.

Anhydrous ammonia has the highest amount of fixation of all the forms of ammonium releasing fertilizers (Young and Cattani, 1962). Since surface applications of ammonium-based $\mathrm{N}$ can be lost to the atmosphere by $70 \%$ from volatilization (Hamid and Mahler, 1994) and nitrate more readily leaches from the soil than ammonia (Blue and Eno, 1954), anhydrous ammonia (AA) has the most potential to increase NUE in single pre-plant applications. Some researchers have agreed that AA moves more in sandy soils with low CEC and low moisture than finer textured soils with high CEC, but under moist conditions and at depths over $10 \mathrm{~cm}$, high rates of AA can be applied with little or no loss from volatilization (Swart et al., 1971; Baker et al., 1959; Blue and Eno, 1954; McDowell and Smith, 1958; Papendick and Parr, 1966). McDowell and Smith (1958) found that ammonia losses were reduced considerably when the applications were changed from 40 -inch to 16 -inch spacings. Swart et al. (1971) supported this research with his own findings that show differences between 102 $\mathrm{cm}$ and $41 \mathrm{~cm}$ (greater yields and less ammonia loss at $41 \mathrm{~cm}$ ), but no differences between $15 \mathrm{~cm}$ and $41 \mathrm{~cm}$. Swart et al. (1971) went on to report while vertical 
movement remains constant ( 4 to $5 \mathrm{~cm}$ ) regardless of $\mathrm{N}$ rate, higher $\mathrm{N}$ rates usually cause greater lateral movement. Other research has suggested that $A A$ decreases $\mathrm{pH}$ and depletes the amount exchangeable $\mathrm{Ca}$ and $\mathrm{Mg}$ leading to decreases in yield due to higher levels of aluminum accumulation (Bouman ef al., 1995; Robbins and Voss, 1989). The objective of this experiment was to determine the effects of tillage and AA application rate and placement on grain yield, grain N, and NUE of hard red winter wheat.

\section{MATERIALS AND METHODS}

Two experimental sites were established in the fall of 2000 , one near Stillwater, OK at the Agronomy Research Station (Easpur loam fine-loamy, mixed, superactive, thermic Fluventic Haplustoll), and one in Lahoma, OK at the North-Central Oklahoma Research Station (Grant silt loam fine-silty, mixed, thermic Udic Argiustoll). Initial soil test results are reported in Table 1. The experiment employed a randomized complete block design with three replications. Individual plots measured $3.0 \times 4.6 \mathrm{~m}$.

Anhydrous ammonia (82-0-0) was applied at rates of 61,123 , and $185 \mathrm{~kg}$ $\mathrm{N} \mathrm{ha}^{-1}$ using two different methods of injection. A rolling coulter applicator (DMI) with five knives spaced $46 \mathrm{~cm}$ apart at a depth of $15 \mathrm{~cm}$, a method commonly used in nitrogen application of winter wheat, was used as one method of AA application. The noble or undercutting blade (V-Blade), an experimental applicator, was used as the other method of AA application. The noble blade applicator has a single coulter, centered in front of the point of the undercutting 
blade, where AA was applied in 10-cm bands at a depth of $10 \mathrm{~cm}$ and a total width of 1.5 meters.

The winter wheat variety 'Jagger' was planted at both sites (planting and fertilizer dates are reported on Table 2). At the Lahoma site, a seeding rate of 95 $\mathrm{kg} \mathrm{ha}^{-1}$ was planted the initial year and increased to $125 \mathrm{~kg} \mathrm{ha}^{-1}$ the second year in 19-cm rows within wheat stubble from the previous year as well as conventionally worked ground. Triple super phosphate $(0-20-0)(N-P-K)$ was applied pre-plant at a rate of $90 \mathrm{~kg} \mathrm{P} \mathrm{ha}^{-1}$ both years at Lahoma to alleviate possible phosphorus deficiencies. At the Efaw site, a rate of $125 \mathrm{~kg} \mathrm{ha}^{-1}$ was planted in 15-cm rows in grain sorghum stubble from the previous summer as well as conventionally worked ground. In this case, conventional tillage at both sites consisted of plowing after wheat harvest, disking throughout the summer, and preparing the seedbed with a field cultivator. Wheat grain was harvested with a Massey Ferguson 8XP experimental combine, removing an area of $2.0 \mathrm{x}$ $4.6 \mathrm{~m}$ from the center of each plot. A Harvest Master yield-monitoring computer installed on the combine was used to record yield data. Grain yield from each plot was determined and a sub-sample was taken for total $\mathbf{N}$ analysis. Grain samples were dried in a forced air oven at $66^{\circ} \mathrm{C}$, ground to pass a 140 mesh sieve (100 um), and analyzed for total N content using a Carlo-Erba NA 1500 automated dry combustion analyzer (Schepers et al., 1989). Analyses of variance and single degree of freedom contrasts were performed using SAS (SAS, 1990). Response indices (RI) were calculated by dividing the highest $\mathrm{N}$ treated grain yield average by the check ( $0 \mathrm{~N}$ rate) average. 


\section{RESULTS AND DISCUSSION}

Grain Yield

Due to delayed planting (Table 2), resulting in poor establishment and little to no tillering, wheat yield responses to applied $\mathbf{N}$ were minimal in 2001 at both locations. However, in $\mathbf{2 0 0 2}$, increased wheat yields were obtained with earlier planting dates and good tiller development, while response to applied $\mathbf{N}$ was still limited. At Efaw a positive linear response to $\mathrm{N}$ using both applicators was observed in the no-till treatments both years (Table 3). A positive linear trend was also observed at Efaw with both applicators in the conventional till treatments in 2001 (Table 3). At Lahoma a positive linear trend was observed in the no-till plots with the knife applicator the initial year. Highly significant positive quadratic responses to $\mathrm{N}$ rate were observed at Lahoma both years for the $\mathrm{V}$ blade applicator in no-till. Statistical analysis did detect a positive quadratic response to the knife applicator the second year at Lahoma in no-till. In 2002 a highly significant advantage was achieved from the V-blade applicator over the knife applicator in no-till at Lahoma. While there were no differences between tillage systems at Efaw the initial year, conventional tillage did result in a slight advantage at Efaw the second year. Similar advantages in yield were observed both years at Lahoma in conventional tillage. It could be speculated that the inconsistency in response to tillage between the two sites was caused by a better seed establishment obtained from the no-till treatments at Efaw being planted into the stubble of a grain sorghum cover crop that reduced soil crusting between 
wheat crops versus being planted into the previous year's wheat stubble. Although not specifically measured, increased $\mathbf{N}$ immobilization was likely present in no-till plots, since a highly significant interaction was found between tillage and $\mathrm{N}$ rate both years at Lahoma along with response indices (RI) values greater in all four site years when compared to conventional-till. However, the lack of an interaction at the Efaw site both years would indicate that the grain sorghum residue is less dense and less resistant to decomposition. This would suggest that the utilization of a summer annual cover crop could increase the effectiveness of a no-till tillage system in Oklahoma. The limited response to applied $\mathbf{N}$ in conventional-till and the moderate response no-till at Efaw and Lahoma both years elucidates the need for us to be able to recognize when the crop has the potential to respond to $\mathrm{N}$.

\section{Grain N Uptake}

Grain $\mathbf{N}$ uptake was consistent with results for grain yield at both locations and both years; low the initial year as was grain yield and relativity high the second year. Positive linear responses to $\mathrm{N}$ rate were detected in both years at Efaw for both applicators and tillage systems (Table 4) At Lahoma, a positive linear response to $\mathbf{N}$ rate was discovered both years for the knife applicator in notill, but was quadratic with the V-blade applicator in no-till. In 2001, knife application of AA increased grain $\mathrm{N}$ uptake over that of the V-blade in no-till at Efaw, but the V-blade increased grain $\mathrm{N}$ uptake over knife application of $A A$ in conventional-till the second year. At Lahoma in 2002, knife application of AA had 
an advantage in conventional-till; conversely the V-blade had an advantage in no-till. Grain N uptake in the conventional tillage system was slightly higher than no-till at Efaw in both years (Table 4). However, there was a highly significant advantage found for grain $\mathrm{N}$ uptake under conventional tillage compared to no-till at Lahoma (Table 4). A significant interaction was found between tillage and $\mathrm{N}$ rate at Lahoma for grain $\mathrm{N}$ uptake, maintaining the consistency established in grain yield that immobilization did take place in the no-till plots.

\section{Nitrogen Use Efficiency}

Nitrogen use efficiency decreased with increasing $\mathrm{N}$ applied at both sites, both years, both tillage systems, and method of AA application. At Efaw, the knife applicator improved NUE over the V-blade in no-till the initial year, but the V-blade applicator increased NUE over knife applied AA in conventional-till the second year. In conventional-till at Lahoma, the V-blade applicator increased NUE over knife applied AA the initial year, while the knife increased NUE over the V-blade the second year. Higher NUE values were observed for the knife compared to V-blade applied AA in no-till the second year at Lahoma. A significant interaction between tillage and $\mathrm{N}$ method was detected both years at Efaw and the second year at Lahoma, further revealing that tillage practices did affect the efficiency of the applicators. In general, there was a trend for increased NUE with the knife application in the no-till tillage system. 


\section{CONCLUSIONS}

Over the two-year period evaluated, conventional tillage significantly increased grain yield and grain $\mathrm{N}$ uptake over no-till at both sites, but, with no significant difference between tillage systems the initial year at Efaw and with the difference between tillage systems greatly reduced the second year at Efaw when no-till was used. While no-till resulted in lower grain yields and grain $\mathbf{N}$ uptake, it did improve NUE at one site year and was maintained at the other three locations compared to conventional-till. This suggests that the expected increase in immobilization in no-till increased the demand for $\mathbf{N}$ and improved NUE. The use of a V-blade applicator with a narrow band placement of $\mathrm{N}$ improved grain yield, grain $\mathrm{N}$, and NUE consistently in conventional-till at three site years, but the V-blade applicator only improved grain yield and grain $\mathrm{N}$ uptake both years at Lahoma over the knife applicator in no-till. The knife applicator actually increased grain yield and grain $\mathrm{N}$ uptake both years in no-till at Efaw and NUE over the V-blade three of the four site years in no-till. This suggests that the V-blade applicator may be advantageous in conventional-till, but the knife applicator may be more beneficial in no-till. Further research in the use of summer cover crops to prevent soil erosion and crusting could improve the potential for no-till and conservational-till in Oklahoma. 


\section{REFERENCES}

Aase, J.K., and J.L. Pikul. 1995. Crop and soil response to long-term tillage practices in the northern Great Plains. Agron. J. 87:652-656.

Allison, F.E. 1973. Soil Organic Matter and its Role in Crop Production. Elsevier Science Publishing Co., Amsterdam.

Baker, J.H., M. Peech, and R.B. Musgrave. 1959. Deterimination of application losses of anhydrous ammonia. Agron. J. 51:361-362.

Bakersman, W.A.P., and C.T. deWit. 1970. Crop husbandry on naturally compacted soils. Neth. J. Agric. Sci. 18:225-246.

Bauer, A., and A.L. Black. 1981. Soil carbon, nitrogen, and bulk density comparisons in two cropland tillage systems after 25 years and in virgin grassland. Soil Sci. Soc. Am. J. 45:1166-1170.

Bauer, A., and A.L. Black. 1994. Quantification of the effect of soil organic matter content on soil productivity. Soil Sci. Soc. Am. J. 58:185-193.

Black, A.L., and L.L. Reitz. 1972. Phosphorus and nitrate-nitrogen immobilization by wheat straw. Agron. J. 64:782-785.

Black, A.L. 1973. Soil property changes associated with crop residue management in a wheat-fallow rotation. Soil Sci. Soc. Proc. 37:943-946.

Blevins, R. L., G.W. Thomas, and P.L. Cornelius. 1977. Influence of no-tillage and nitrogen fertilization on certain soil properties after 5 years of continuous corn. Agron. J. 69:383-386.

Blevins, R.L., G.W. Thomas, M.S. Smith, W.W. Frye, and P.L. Cornelius. 1983. Changes in soil properties after 10 years continuous non-tilled and conventionally tilled corn. Agron. J. 3:135-146.

Blue, W.G., and C.F. Eno. 1954. Distribution and retention of anhydrous ammonia in sandy soils. Soil Sci. Soc. Amer. Proc. 18:420-424.

Bonfil, D.J., I. Mufradi, S. Klitman, and S. Asido. 1999. Wheat grain yield and soil profile water distribution in a no-till arid environment. Agron. J. 91:368373.

Bouman, O.T., D. Curtin, C.A. Campbell, V.O. Biederbeck, and H. Ukrainetz. 1995. Soil acidification from long-term use of anhydrous ammonia and urea. Soil Sci. Soc. Am. J. 59:1488-1494. 
Brenneman, L.G., and J.M. Laflen. 1982. Modeling sediment deposition behind corn residue. Trans. ASAE. 25:1245-1250.

Bruce, R.R., G.W. Langdale, and A.L. Dillard. 1990. Tillage and crop rotation effect on characteristics of a sandy surface soil. Soil Sci. Soc. Am. J. 54:1744-1747.

Campbell, C.A., and R.P. Zenter. 1993. Soil organic matter as influenced by crop rotations and fertilization. Soil Sci. Soc. Am. J. 57:1034-1040.

Cantero-Martinez, C., G.J. O'Leary, and D.J. Connor. 1999. Soil water and nitrogen interaction in wheat in a dry season under a fallow-wheat cropping system. Australian Journal of Experimental Agriculture. 39:2937.

Christensen, N.B., W.C. Lindemann, E. Salazar-Sosa, and L.R. Gill. 1994. Nitrogen and carbon dynamics in no-till and stubble mulch tillage systems. Agron. J. 86:298-303.

Cochran, V.L., L.F. Elliot, and R.I. Papendick. 1980. Carbon and nitrogen movement under surface applied wheat (Triticum aestivum) straw. Soil Sci. Soc. Am. J. 44:978-982.

Cogo, N.P., W.C. Moldenhauer, and G.R. Foster. 1984. Soil loss reductions from conservation tillage practices. Soil Sci. Soc. Am. J. 48:368-373.

Dao, T.H. 1993. Tillage and winter wheat residue management effects on water infiltration and storage. Soil Sci. Am. J. 57:1586-1595.

Dick, W.A. 1983. Organic carbon, nitrogen, and phosphorus concentrations and $\mathrm{pH}$ in soil profiles as affected by tillage intensity. Soil Sci. Soc. Am. J. 47:102-107.

Dodge, D.A., and H.E. Jones. 1948. The effect of long-time fertility treatments on the nitrogen and carbon content of a prairie soil. J. Am. Soc. Agron. 40:478-485.

Doran, J.W. 1980. Soil microbial and biochemical changes associated with reduced tillage. Soil Sci. Soc. Am. J. 44:765-771.

Dowdell, R.J., and R.Q. Cannell. 1975. Effect of ploughing and direct drilling on soil nitrate content. J. Soil. Sci. 26:53-61.

Dowdell, R.J., and R. Crees. 1980. The uptake of $\mathrm{N}$-labeled fertilizer by winter wheat and its immobilization in a clay soil after direct drilling or plowing. J. Sci. Food Agric. 31:992-996. 
Eck, H. V., and O.R. Jones. 1992. Soil nitrogen status as affected by tillage, crops, and crop sequences. Agron. J. 84:660-668.

Edwards, W.M., M.J. Shipitalo, L.B. Owens, and L.D. Norton. 1990. Effect of Lumbricus terrestris $L$. burrows on hydrology of continuous no-till corn fields. Geoderma 46:73-84.

Eghball, B., L.N. Mielke, D.L. McCallister, and J.W. Doran. 1994. Distribution of organic carbon and inorganic nitrogen in soil under various tillage and crop sequences. J, Soil Water ConServ. 49:201-205.

Elliott, E.T., P.W. Tracy, G.A. Peterson, and C.V. Cole. 1986. Leaching of mineralized $\mathbf{N}$ is less under no-till cultivation. P. 53-54. In Trans. Int. Congr. Soil Sci. $13^{\text {th }}$, Hamburg, Germany. Vol. 6. Congr. Centurum, Hamburg.

Entz, M.H., and D.B. Fowler. 1991. Agronomic performance of winter versus spring wheat. Agron. J. 83:527-532.

Fenster, C.R., and G.A. Peterson. 1979. Effects of no-tillage fallow compared to conventional tillage in a wheat-fallow system. Nebraska Agic. Exp. Bull. 289.

Follett, R.F., and D.S. Schimel. 1989. Effect of tillage practices on microbial biomass dynamics. Soil Sci. Soc. Am. J. 53:1091-1096.

Fox, R.H., and V.A. Bandel. 1986. Nitrogen utilization with no-tillage. In M.A. Sprague and Triplett (eds) No-tillage and surface tillage agriculture, the tillage revolution. P. 117-148. John Wiley and Sons, New York.

Groffman, P.M. 1984. Nitrification and denitrification in conventional and notillage soils. Soil Sci. Soc. Am. J. 49:329-334.

Haas, H.J., C.E. Evans, and E.F. Miles. 1957. Carbon and nitrogen changes in Great Plains soils as influenced by cropping and soil treatments. USDA Tech. Bull. 1164. U.S. Gov. Print. Office, Washington, DC.

Halvorson, A.D., A. L. Black, J.M. Krupinsky, and Stephen D. Merrill. 1999. Dryland winter wheat response to tillage and nitrogen within an annual cropping system. Agron. J. 91:702-707.

Hamid, A., and R.L. Mahler. 1994. The potential for volatilization losses of applied nitrogen fertilizers from northern Idaho soils. Commun. Soil. Sci. Plant Anal. 25(3\&4), 361-373. 
Hobbs, L.A., and P.L. Brown. 1957. Nitrogen and organic carbon changes in cultivated western Kansas soils. Kansas Agric. Exp. Stn. Tech. Bull. 89.

Holland, J.F., and W.L. Felton. 1989. Effect of tillage practice on grain sorghum production in northem New South Wales. Aust. J. Exp. Agric. 29:843-848.

Ismail, I., R.L. Blevins, and W.W. Frye. 1994. Long-term no-tillage effects on soil properties and continuous com yields. Soil Sci. Soc. Am. J. 58:193-198.

Jones, O.R., and T.W. Popham. 1997. Cropping and tillage systems for dryland grain production in the southern high plains. Agron. J. 89:222-232.

King, K.W., D.C. Flanagan, L.D. Norton, and J.M. Laflen. 1995. Rill erodibility parameters influenced by long-term management practices. Trans. ASAE. 38:159-164.

Kirkegaard, J.A., R. Munns, R.A. James, P.A. Gardner, and J.F. Angus. 1995. Reduced growth and yield of wheat with conservation cropping: II. Soil biological factors limit growth under direct drilling. Aust. J. Agric. Res. 46:75-88.

Kitur, B.K., M.S. Smith, R.L. Blevins, and W.W. Frye. 1984. Fate of N-depleted ammonium nitrate applied to no-tillage and conventional tillage corn. Agron. J. 76:240-242.

Knowles, T.C., B.W. Hipp, P.S. Graff, and D.S. Marshall. 1993. Nitrogen nutrition of rainfed winter wheat in tilled and no-till sorghum and wheat residues. Agron. J. 85:886-893.

Kolberg, R.L., N.R. Kitchen, D.G. Westfall, and G.A. Peterson. 1996. Cropping intensity and nitrogen management impact of dryland no-till rotations in the semi-arid Western Great Plains. J. Prod. Agric. 9:517-522.

Lal, R., A.A. Mahboubi, and N.R. Fausey. 1994. Long-term tillage effect and rotation effects on properties of a central Ohio soil. Soil Sci. Soc. Am. J. 58:517-522.

Lamb, J.A., G.A. Peterson, and C.R. Fenster. 1985. Wheat-fallow tillage systems 'effect on newly cultivated grassland soils' nitrogen budget. Soil Sci. Soc. Am. J. 49:352-356.

Lembi, C.A., M.D. Bri Hon, and M.A. Ross. 1985. Evaluation of nitrogen application technique and tillage system on nitrogen runoff from an erodible soil. Technical Report 174. Purdue Univ., West Lafayette, Ind. 
Lopez-Bellido, L., M. Fuentes, J.E. Castillo, F.J. Lopez-Garrido, and E.J. Fernandez. 1996. Long-term tillage, crop rotation and nitrogen fertilizer effects on wheat yield under rainfed Mediterranean conditions. Agron. J. 88:783-791.

Lupwayi, N.Z., W.A. Rice, and G.W. Clayton. 1998. Soil microbial diversity and community structure under wheat as influenced by tillage and crop rotation. Soil Biol. Biochem. 30:1733-1742.

McDowell, L. L., and G.E. Smith. 1958. The retention and reactions of anhydrous ammonia on different soil types. Soil Sci. Soc. Amer. Proc. 22:38-42.

McGregor, K.C., C.K. Mutchler, and R.K. Cullum.1992. Soil erosion effects on soybean yields. Trans. ASAE. 35:1521-1525.

McGregor, K.C., R.F. Cullum, and C.K. Mutchler. 1999. Long-term management effects on runoff, erosion, and crop production. Trans. ASAE. 42:99-105.

Mclsaac, G.F., J.K. Mitchell, and M.C. Hirshi. 1990. Contour and conservation tillage for corn and soybeans in Tama silt loam soil. Hydraulics and sediment concentrations. Trans. ASAE. 33:1541-1550.

Merrill, S.D., A.L. Black, and A. Bauer. 1996. Conservation tillage affects root growth of dryland spring wheat under drought. Soil Sci. Am. J. 60:575583.

Mielke, L.N., J.W. Doran, and K.A. Richards. 1986. Physical environment near the surface of plowed and no-tilled soils. Soil Tillage Res. 7:355-366.

Norwood, C. 1994. Profile water distribution and grain yield as affected by cropping system and tillage. Agron. J. 86:558-563.

Papendick, R.I. and J.F. Parr. 1966. Retention of anhydrous ammonia by soil: III. Dispensing apparatus and resulting ammonia distribution. Soil Sci. 102:193-201.

Pesant, A.R., J.L. Dionne, and J. Genest. 1987. Soil and nutrient losses in surface runoff from conventional and no-till corn systems. Can. J. Soil Sci. 67:835-843.

Peterson, G.A., A.J. Schlegel, D.L. Tanaka, and O.R. Jones. 1996. Precipitation use efficiency as affected by cropping and tillage systems. J. Prod. Agric. 9:180186.

Pikul, J.L., Jr., and J.K. Aase. 1995. Infiltration and soil properties as affected by annual cropping in the northern Great Plains. Agron. J. 87:656-662. 
Rao, S.C., and T. H. Dao. 1996. Nitrogen placement and tillage effects on dry matter and nitrogen accumulation and redistribution in winter wheat. Agron. J. 88:365-371.

Rhoton, F.E., R.R. Bruce, N.W. Buehring, G.B. Elkins, C.W. Langdale, and D.D. Tyler. 1993. Chemical and physical characteristics of four soil types under conventional and no-tillage systems. Soil Tillage Res. 28:51-61.

Rice, C.W., and M.S. Smith. 1982. Denitrification in no-till and plowed soils. Soil Sci. Soc. Am. J. 46:1168-1173.

Rice, C.W., and M.S. Smith. 1984. Short-term immobilization of fertilizer nitrogen at the surface of no-till and plowed soils. Soil Sci. Soc. Am. J. 48:295-297.

Ridley, A.O., and R.A. Hedlin. 1968. Soil organic matter and crop yields as influenced by frequency of summerfallowing. Can. J. Soil Sci. 48:315-322.

Robbins, S.G., and R.D. Voss. 1989. Division S-8-fertilizer technology and use acidic zones from ammonia application in conservation tillage systems. Soil Sci. Soc. Am. J. 53:1256-1263.

Rodriguez, M.B., and N. Giambiagi. 1995. Denitrification in tillage and no-tillage Pampean soils: relationships among soil water, available carbon, and nitrate and nitrous oxide production. Commun. Soil. Sci. Plant Anal. 26:3205-3220.

SAS Institute. 1990. SAS/STAT user's guide. Release 6.03 ed. SAS Inst., Cary, NC.

Schepers, J.L., and R.A. Cattani. 1962. Mineral fixation of anhydrous ammonia by air-dry soils. Soil Sci. Soc. Am. Proc. 26:147-152.

Smika, D.E., and P.W. Unger. 1986. Effect of surface residues on soil water storage. Adv. Soil. Sci. 5:111-138.

Smith, S.J., and A.N. Sharpley. 1990. Soil nitrogen mineralization in the presense of surface and incorporated crop residues. Agron. J. 82:112116.

Smith, S.J., A.N. Sharpley, J.W. Naney, W.A. Berg, and O.R. Jones. 1991. Water Quality impacts associated with wheat culture in the southern Plains. J. Environ. Qual. 20:244-249.

Soper, R.J., G.J. Racz, and P.I. Fehr. 1971. Nitrate nitrogen in the soil as a means of predicting the fertilizer nitrogen requirements of barley. Can. J. Soil Sci. 51:45-49. 
Stinner, B.R., G.D. Hoyt, and R.L. Todd. 1983. Changes in soil chemical properties following a 12-year fallow: A 2-year comparison of conventional tillage and no-tillage agroecosystems. Soil Tillage Res. 3:277-290.

Swart, C.L., L.S. Murphy, and C.W. Swallow. 1971. Retention patterns and effectiveness of anhydrous ammonia applied with an undercutting blade. Agron. J. 63:881-884.

Toews, W.H., and R.J. Soper. 1978. Effects of nitrogen sources, method of placement and soil type on seedling emergence and barley crop yields. Can. J. Soil Sci. 58:311-320.

Tomar, J.S., and R.J. Soper. 1981. Fate of tagged urea $\mathbf{N}$ in field with different methods of $\mathrm{N}$ and organic matter placement. Agron. J. 73:991-995.

Unger, P.W. 1991. Organic matter, nutrient, and pH distribution in no- and conventional-tillage semiarid soils. Agron. J. 83:186-189.

Vyn, T.J., and B.A. Raimbault. 1993. Long-term effect of five tillage systems on corn response and soil structure. Agron. J. 85:1074-1079.

Waddell, J.T., and R.R. Weil. 1996. Water distribution in soil under ridge-till and no-till corn. Soil Sci. Soc. Am. J. 60:230-237.

Wagger, M.G., D.E. Kissel, and S.J. Smith. 1985. Mineralization of nitrogen from nitrogen-15 labeled crop residues under field conditions. Soil Sci. Soc. Am. J. 49:1220-1226.

Weersink, A., M. Walker, C. Swanton, and J.E. Shaw. 1992. Costs of conventional and conservation tillage systems. J. Soil and Water Cons. 47:328-334.

Wienhold, B.J., and A.D. Halvorson. 1999. Nitrogen mineralization responses to cropping, tillage, and nitrogen rate in the northern great plains. Soil Sci. Soc. Am. J. 63:192-196.

Wood, C.W., D.G. Westfall, and G.A. Peterson. 1991. Soil carbon and nitrogen on initiation of no-till cropping systems. Soil Sci. Soc. Am. J. 55:470-476.

Young, R.A., J.C. Zubriski, and E.B. Norum. 1960. Influence of long-term fertility management practices on chemical and physical properties of a Fargo clay. Soil Sci. Soc. Am. J. 24:124-128.

Table 1. Initial surface $(0-15 \mathrm{~cm})$ and sub-soil $(15-30 \mathrm{~cm})$ test results prior to experiment 
initiation at Efaw and Lahoma OK.

\begin{tabular}{lccccc}
\hline & $\mathrm{NH}_{4}-\mathrm{N}$ & $\mathrm{NO}_{3}-\mathrm{N}$ & $\mathrm{P}$ & $\mathrm{K}$ & \\
\cline { 2 - 6 } Sample & & & $\mathrm{mg} \mathrm{kg}^{-1}$ & & $\mathrm{pH}$ \\
\hline Lahoma $(0-15 \mathrm{~cm})$ & 14.35 & 8.86 & 9.34 & 282 & 5.67 \\
Lahoma $(15-30 \mathrm{~cm})$ & 15.78 & 3.89 & 6.49 & 222 & 6.23 \\
Efaw $(0-15 \mathrm{~cm})$ & 15.87 & 11.16 & 28.23 & 225 & 5.70 \\
Efaw $(15-30 \mathrm{~cm})$ & 13.70 & 7.41 & 7.44 & 190 & 6.35 \\
\hline
\end{tabular}

$\mathrm{NH}_{4}-\mathrm{N}$ and $\mathrm{NO}_{3}-\mathrm{N}-2 \mathrm{M} \mathrm{KCL}$ extract; $\mathrm{P}$ and $\mathrm{K}-$ Mehlich-3 extraction; $\mathrm{pH}-1: 1$ soil:deionized water

Table 2. Planting, fertilizer, and harvest dates at Efaw and Lahoma, OK, 2000-02.

\begin{tabular}{lcccc}
\hline Location & Crop Year & Planting & $\begin{array}{c}\text { Fertilizer } \\
\text { Application }\end{array}$ & Grain Harvest \\
\hline Lahoma & $2000-2001$ & $11-27-00$ & $11-27-00$ & $6-14-01$ \\
Efaw & $2000-2001$ & $11-30-00$ & $11-22-00$ & $6-11-01$ \\
Lahoma & $2001-2002$ & $10-03-01$ & $9-04-01$ & $6-25-02$ \\
Efaw & $2001-2002$ & $10-01-01$ & $9-11-01$ & $6-21-02$ \\
\hline
\end{tabular}


Table 3. Grain yield treatment means and analysis of variance at Efaw and Lahoma, 2001-2002.

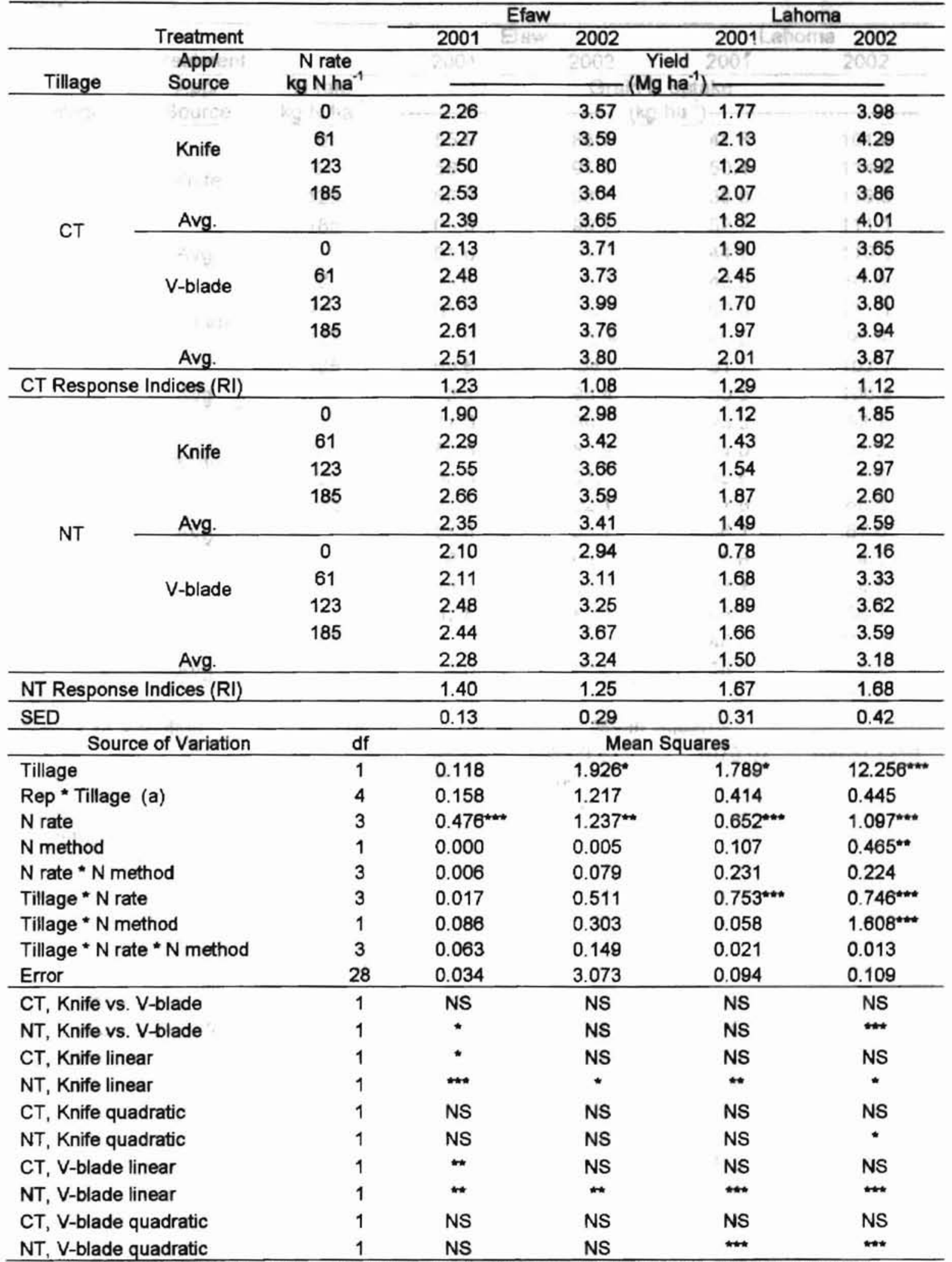

NT, V-blade quadratic

$\because *$ Significant at the $0.10,0.05$, and 0.01 levels of probability, respectively; $N S$ is not significant. SED is the standard error of the difference between two equally replicated means.

Mean squares not followed by a symbol are not significant. $C T=$ conventional tillage; $N T=$ no-till

$\mathrm{RI}=$ highest $\mathrm{N}$ treated grain yield average divided by the check ( $\mathrm{N}$ rate) average. 
Table 4. Grain $\mathbf{N}$ uptake treatment means and analysis of variance at Efaw and Lahoma, 20012002.

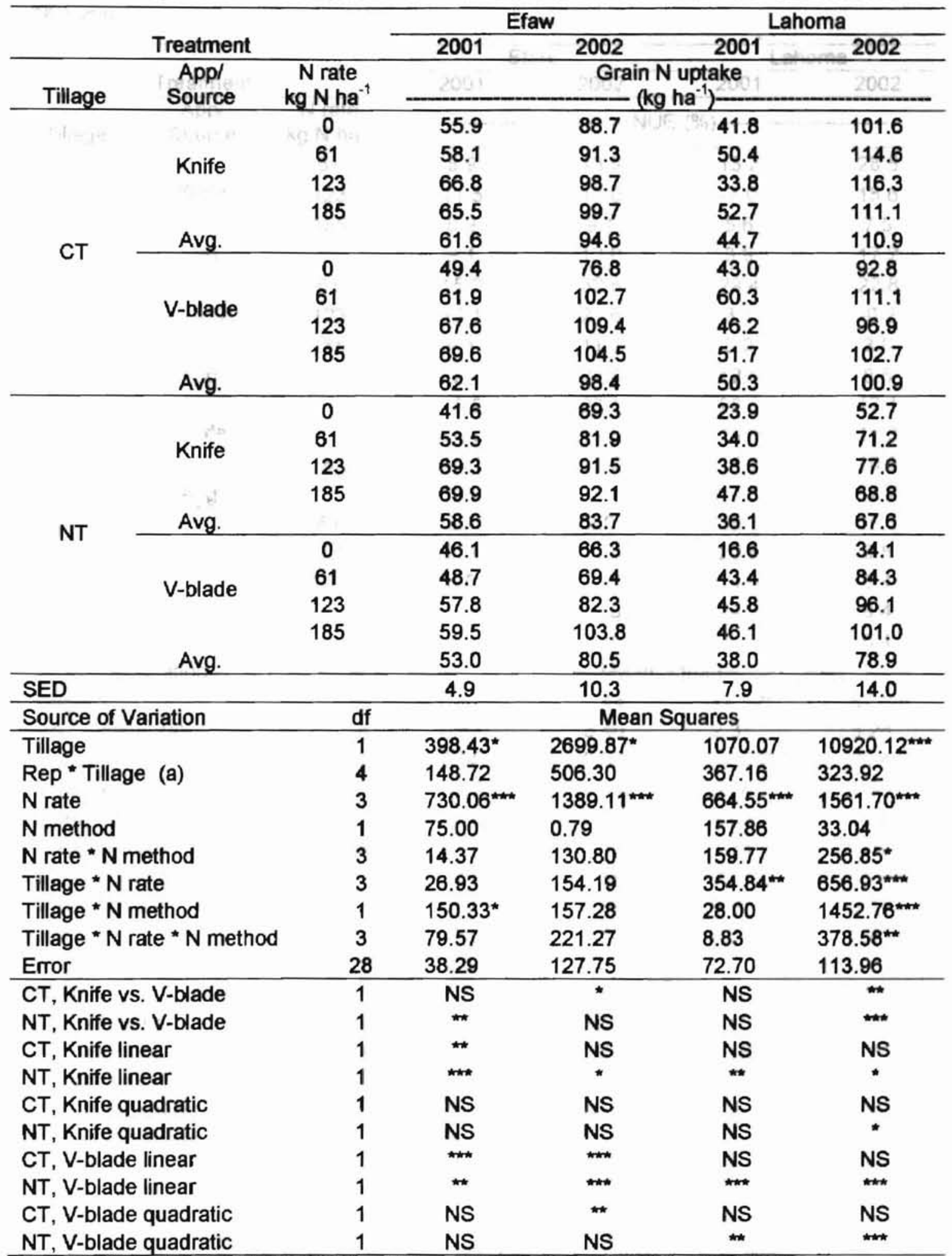
SED is the standard error of the difference between two equally replicated means.

Mean squares not followed by a symbol are not significant.

$\mathrm{CT}=$ conventional tillage; $\mathrm{NT}=$ no-till 
Table 5. Nitrogen Use Efficiency treatment means and analysis of variance at Efaw and Lahoma, 2001-2002.

\begin{tabular}{|c|c|c|c|c|c|c|}
\hline \multirow{2}{*}{\multicolumn{3}{|c|}{ Treatment }} & \multicolumn{2}{|c|}{ Efaw } & \multicolumn{2}{|c|}{ Lahoma } \\
\hline & & & 2001 & 2002 & 2001 & 2002 \\
\hline Tillage & $\begin{array}{c}\text { Appl } \\
\text { Source }\end{array}$ & 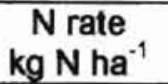 & \multicolumn{4}{|c|}{ NUE (\%) _ _ } \\
\hline \multirow{8}{*}{ CT } & \multirow{3}{*}{ Knife } & 61 & 8.9 & 13.9 & 13.2 & 28.5 \\
\hline & & 123 & 11.5 & 13.0 & -7.0 & 15.6 \\
\hline & & 185 & 6.9 & 9.1 & 5.6 & 7.5 \\
\hline & \multicolumn{2}{|l|}{ Avg. } & 9.1 & 12.0 & 3.9 & 17.2 \\
\hline & \multirow{3}{*}{ V-blade } & 61 & 15.0 & 32.6 & 29.4 & 22.8 \\
\hline & & 123 & 12.1 & 21.6 & 3.1 & -0.2 \\
\hline & & 185 & 9.1 & 11.7 & 5.0 & 3.0 \\
\hline & \multicolumn{2}{|l|}{ Avg. } & 12.1 & 22.0 & 12.5 & 8.5 \\
\hline \multirow{8}{*}{ NT } & \multirow{3}{*}{ Knife } & 61 & 15.9 & 23.1 & 22.6 & 17.1 \\
\hline & & 123 & 20.7 & 19.3 & 15.0 & 11.3 \\
\hline & & 185 & 14.1 & 11.2 & 14.9 & 10.3 \\
\hline & \multicolumn{2}{|l|}{ Avg. } & 16.9 & 17.9 & 17.5 & 12.9 \\
\hline & \multirow{3}{*}{ V-blade } & 61 & 8.1 & 2.6 & 38.1 & 15.1 \\
\hline & & 123 & 11.4 & 11.8 & 20.8 & 9.8 \\
\hline & & 185 & 8.5 & 19.4 & 14.0 & 3.4 \\
\hline & \multicolumn{2}{|l|}{ Avg. } & 9.3 & 11.3 & 24.3 & 9.4 \\
\hline \multicolumn{3}{|l|}{ SED } & 4.2 & 8.8 & 6.1 & 6.4 \\
\hline \multicolumn{2}{|c|}{ Source of Variation } & df & \multicolumn{4}{|c|}{ Mean Squares } \\
\hline \multicolumn{2}{|c|}{ Tillage } & 1 & 0.57 & 0.44 & $14.52^{\star}$ & $57.00^{\text {th }}$ \\
\hline \multicolumn{2}{|c|}{ Rep* Tillage (a) } & 4 & 0.43 & 3.40 & 2.31 & 3.28 \\
\hline \multicolumn{2}{|c|}{$\mathrm{N}$ rate } & 2 & 0.55 & 0.58 & $11.53^{* \ldots}$ & $23.47^{* n+1}$ \\
\hline \multicolumn{2}{|c|}{$\mathrm{N}$ method } & 1 & 0.47 & 0.14 & $5.34^{\text {m*n}}$ & 1.83 \\
\hline \multicolumn{2}{|c|}{$\mathrm{N}$ rate ${ }^{*} \mathrm{~N}$ method } & 2 & 0.10 & 0.21 & 2.06 & 0.58 \\
\hline \multicolumn{2}{|c|}{ Tillage * $\mathrm{N}$ rate } & 2 & 0.15 & 2.13 & 1.16 & 1.50 \\
\hline \multicolumn{2}{|c|}{ Tillage * $\mathrm{N}$ method } & 1 & $2.52^{\text {*t }}$ & $7.56^{\star}$ & 0.07 & $15.98^{\text {*n** }}$ \\
\hline Tillage $* 1$ & te ${ }^{*} \mathrm{~N}$ method & 2 & 0.07 & 2.96 & 0.03 & 0.15 \\
\hline Error & & 20 & 0.40 & 1.80 & 0.83 & 0.91 \\
\hline CT, Knife & V-blade & 1 & NS & 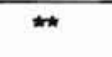 & " & * \\
\hline NT, Knife & V-blade & 1 & $* *$ & NS & NS & *** \\
\hline CT, Knife & & 1 & NS & NS & 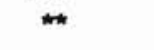 & $\star \star$ \\
\hline NT, Knife & & 1 & NS & NS & NS & $m$ \\
\hline CT, Knife & adratic & 1 & NS & NS & NS & NS \\
\hline NT, Knife & adratic & 1 & NS & NS & NS & NS \\
\hline CT, V-bla & linear & 1 & NS & $\star *$ & 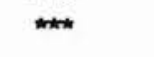 & $* *$ \\
\hline NT, V-bla & linear & 1 & NS & NS & w* & thot \\
\hline CT, V-bla & quadratic & 1 & NS & NS & $\star$ & $\star$ \\
\hline NT, V-bla & quadratic & 1 & NS & NS & NS & NS \\
\hline
\end{tabular}

$\because * * * *$ Significant at the $0.10,0.05$, and 0.01 levels of probability, respectively; $N S$ is not significant.

NUE = (Grain N uptake of $N$ treatment - Grain $N$ uptake of check) / $N$ rate

SED is the standard error of the difference between two equally replicated means.

Mean squares not followed by a symbol are not significant.

$\mathrm{CT}=$ conventional tillage; $\mathrm{NT}=$ no-till 


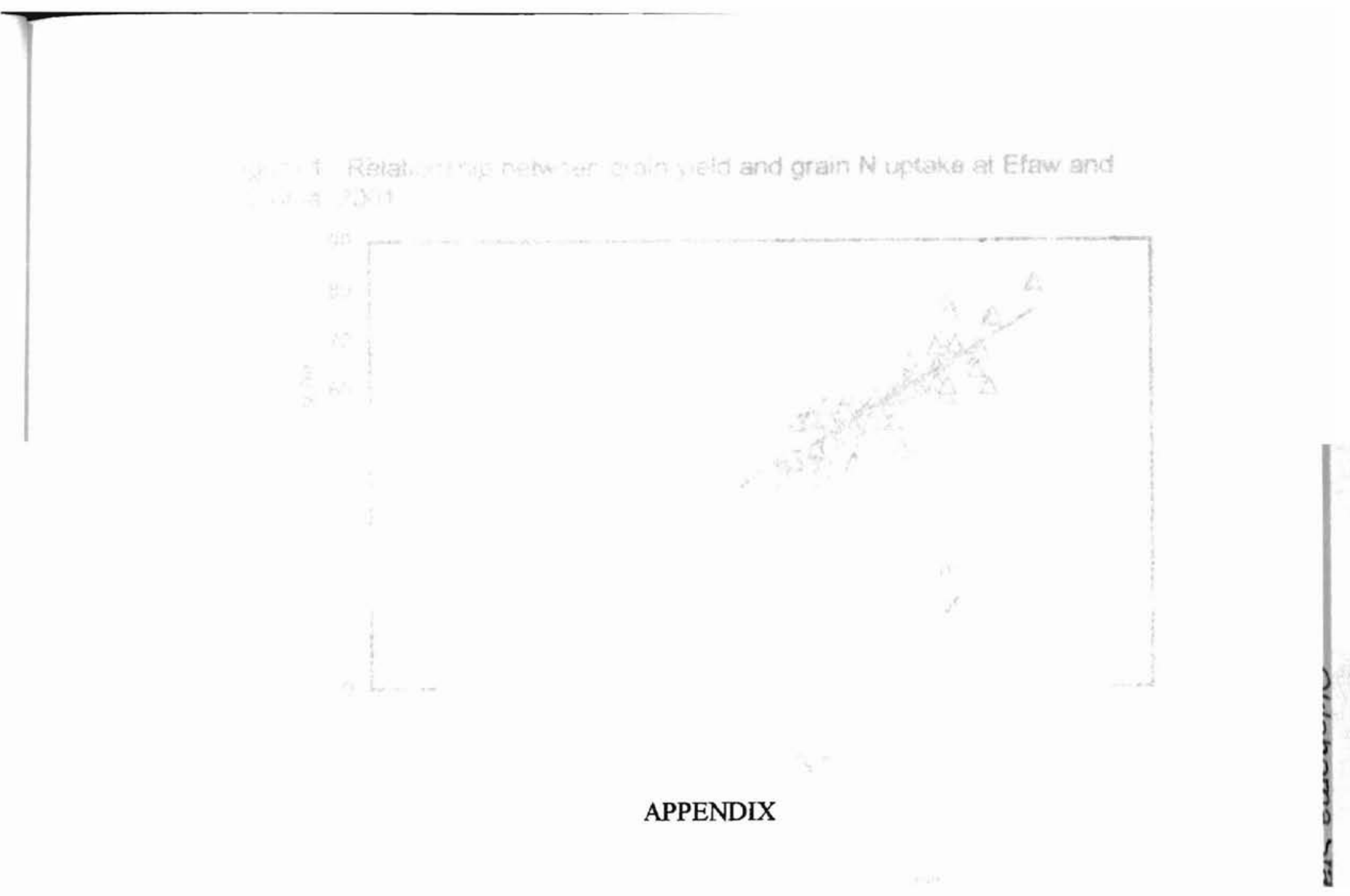

APPENDIX 
Figure 1. Relationship between grain yield and grain $\mathbf{N}$ uptake at Efaw and Lahoma, 2001.

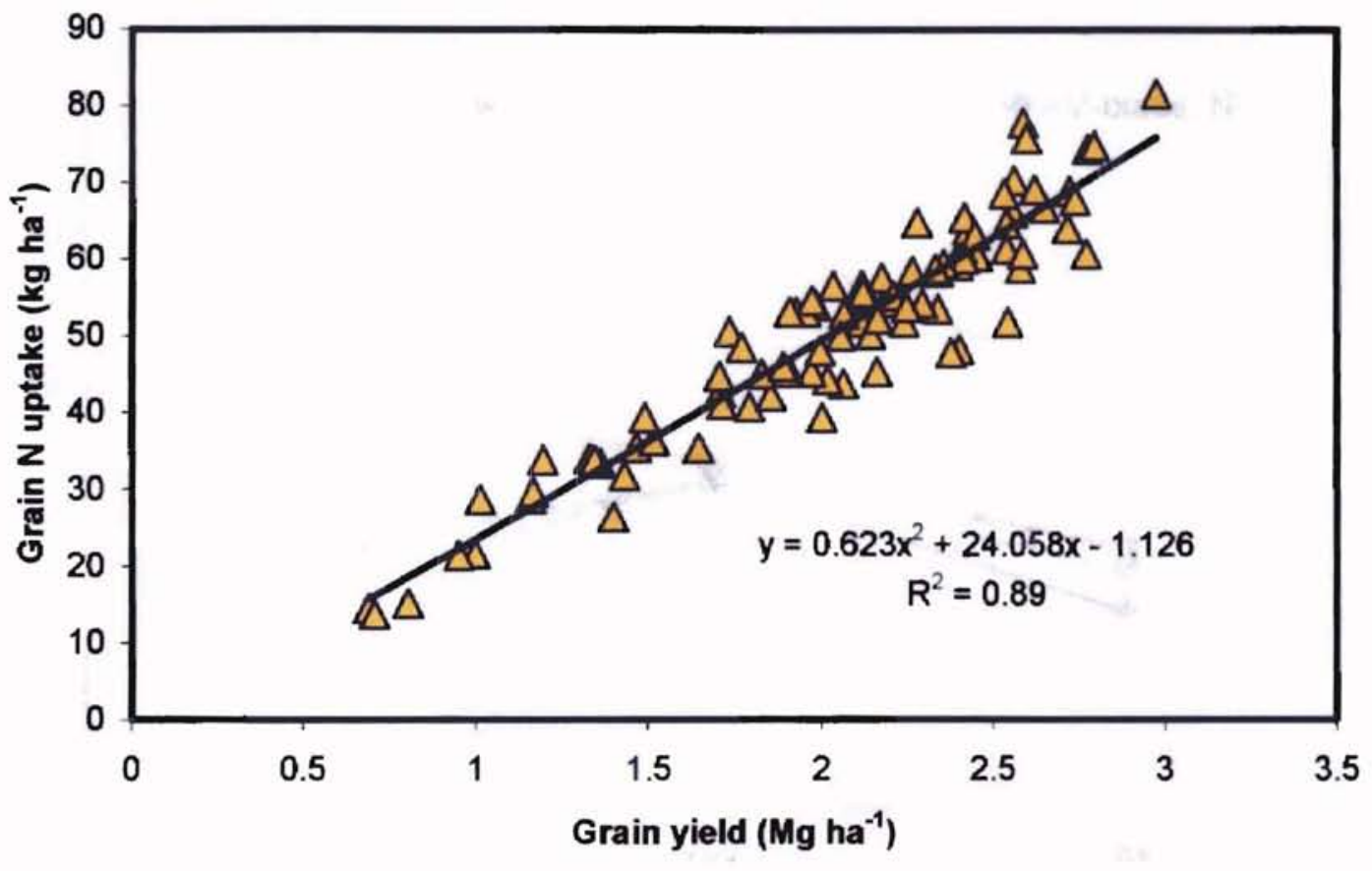

Figure 2. Relationship between grain yield and grain $\mathbf{N}$ uptake at Efaw and Lahoma, 2002.

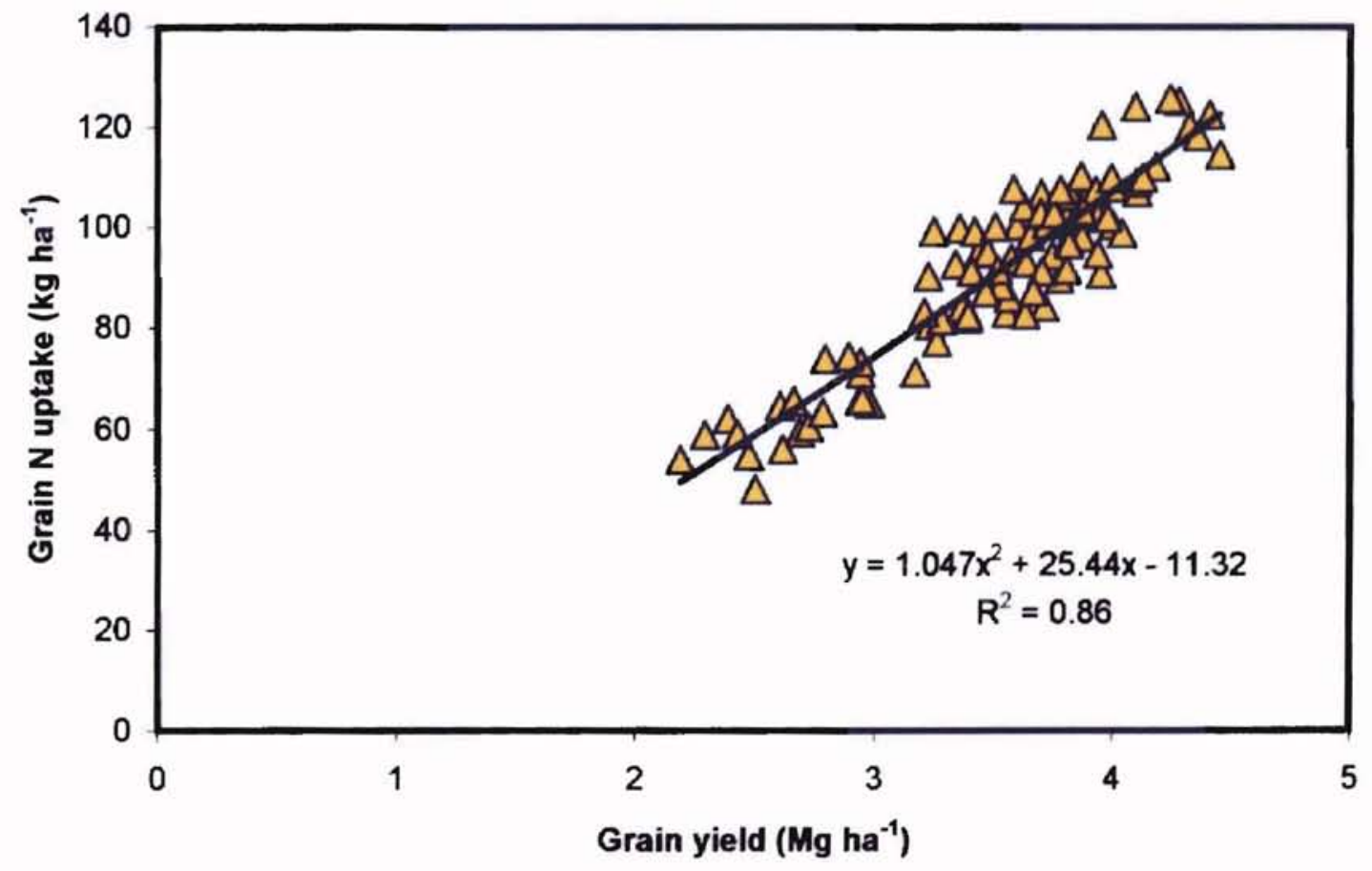


Figure 3. Effect of $\mathbf{N}$ rate, $\mathbf{N}$ method, and tillage on nitrogen use efficiency at Efaw, OK, 2001.

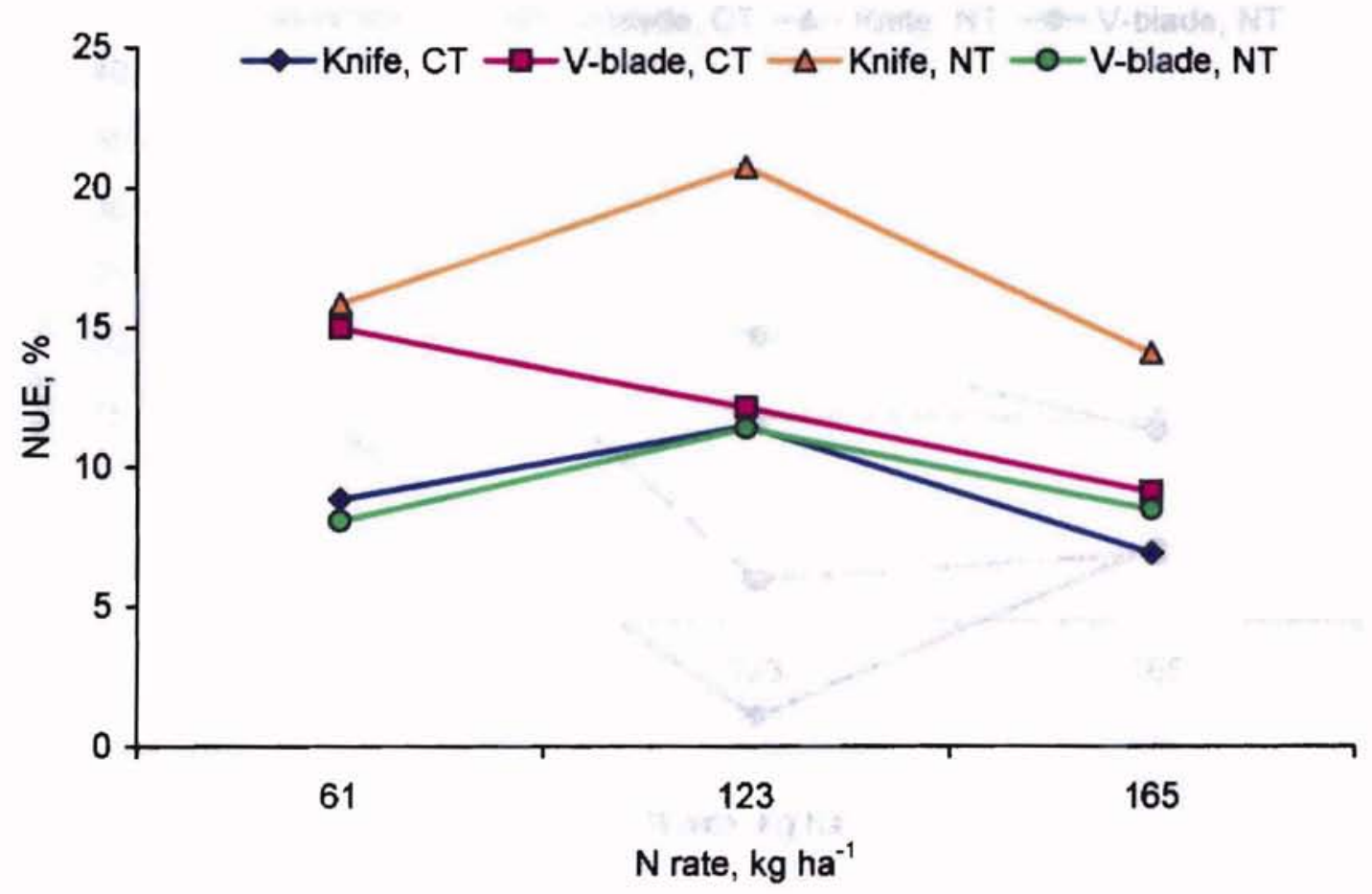


Figure 4. Effect of $\mathbf{N}$ rate, $\mathbf{N}$ method, and tillage on nitrogen use efficiency at Lahoma, OK, 2001.

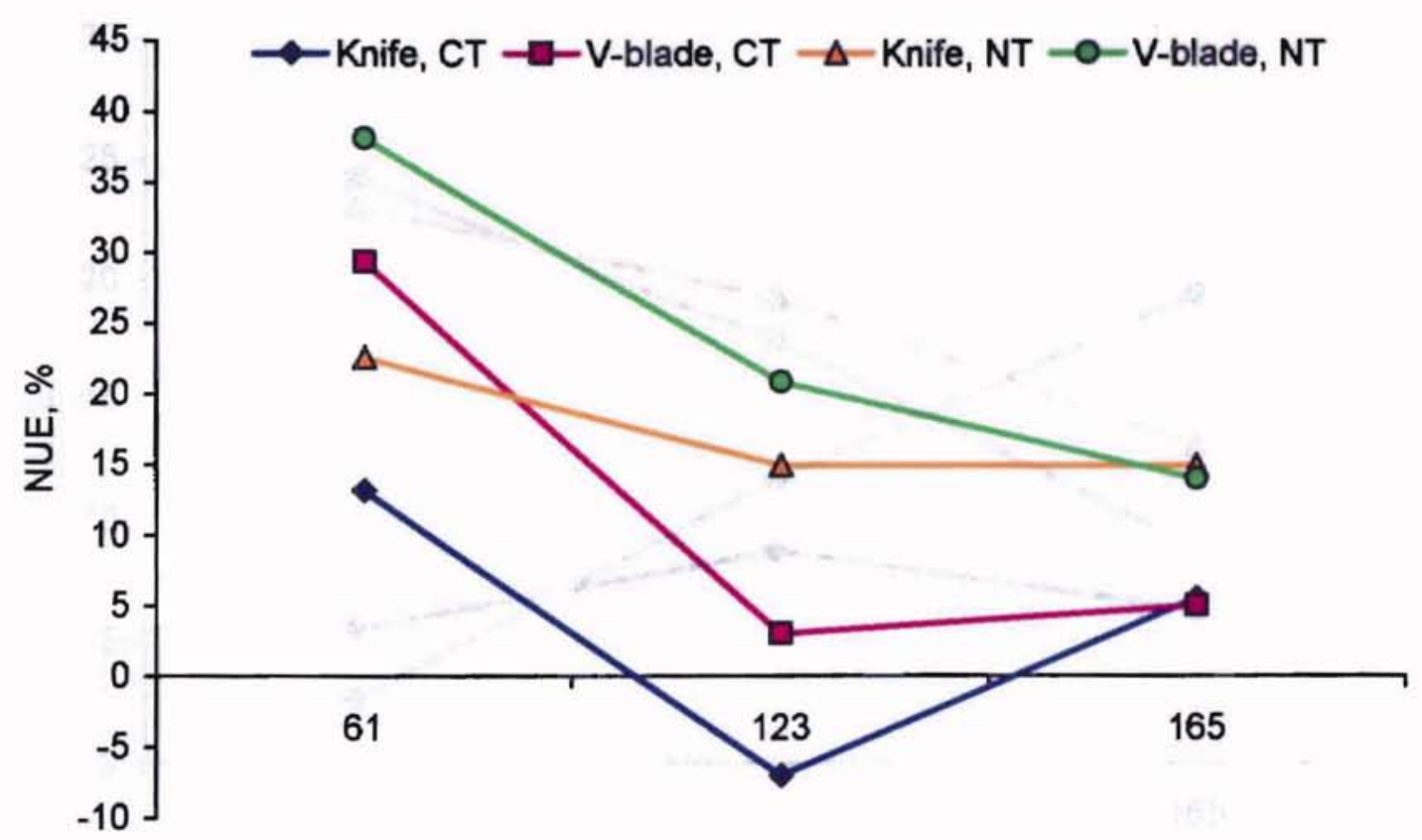

$\mathrm{N}$ rate, $\mathrm{kg} \mathrm{ha}^{-1}$ 
Figure 5. Effect of $\mathrm{N}$ rate, $\mathrm{N}$ method, and tillage on nitrogen use efficiency at Efaw, OK, 2002.

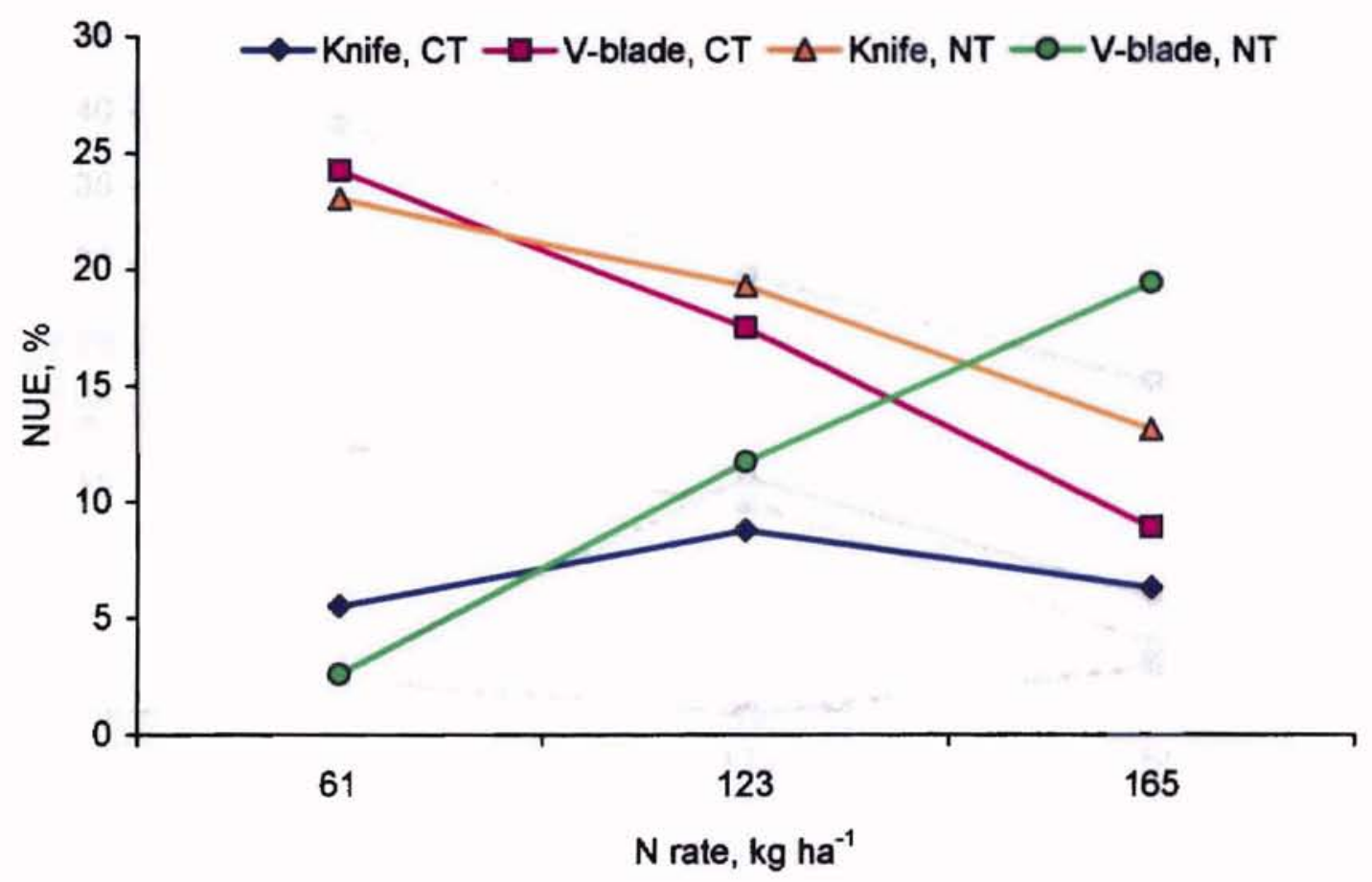


Figure 6. Effect of $\mathbf{N}$ rate, $\mathrm{N}$ method, and tillage on nitrogen use efficiency at Lahoma, OK, 2002.

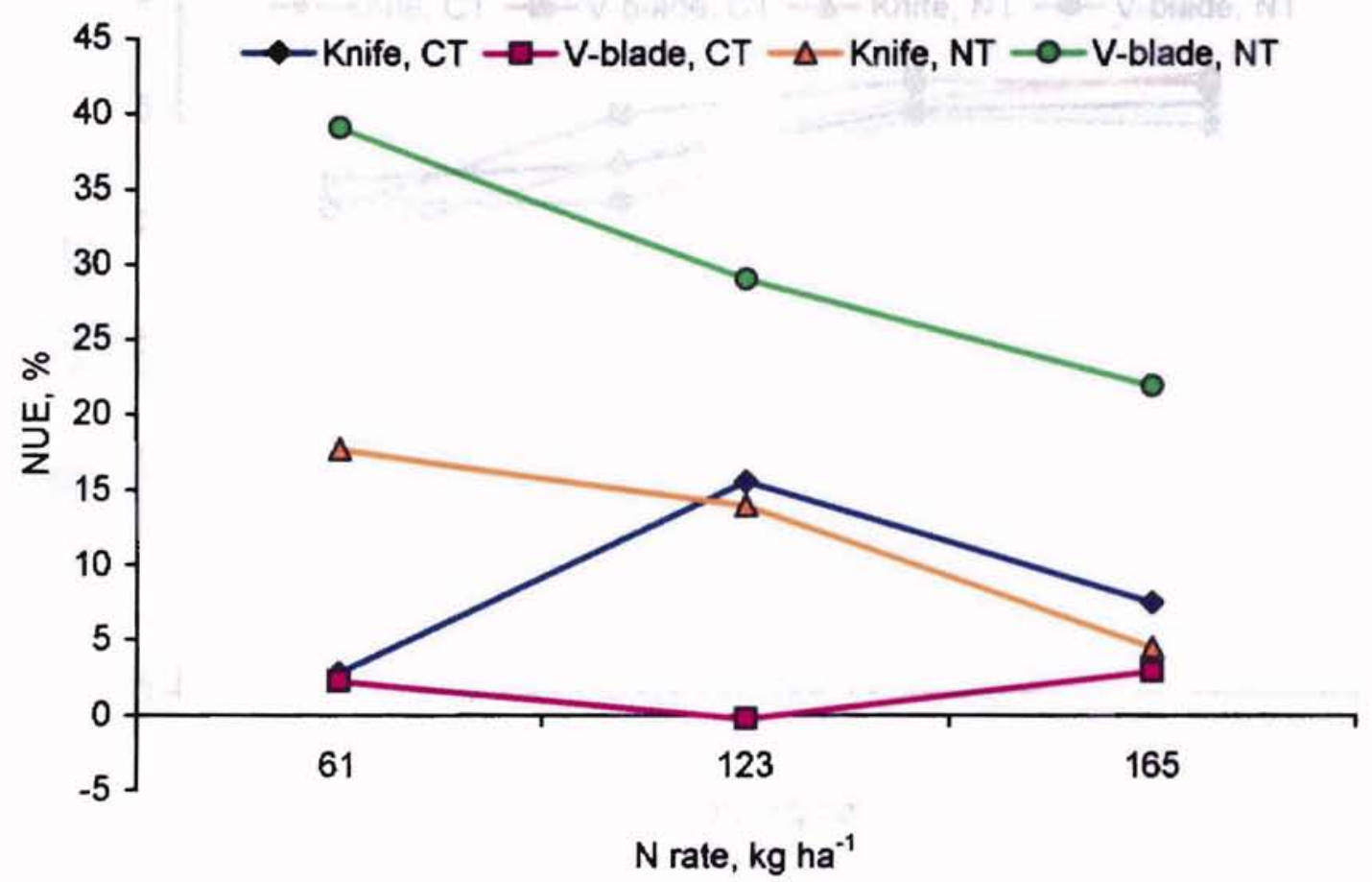


Figure 7. Effect of $\mathbf{N}$ rate, $\mathbf{N}$ method, and tillage on grain yield at Efaw, OK, 2001.

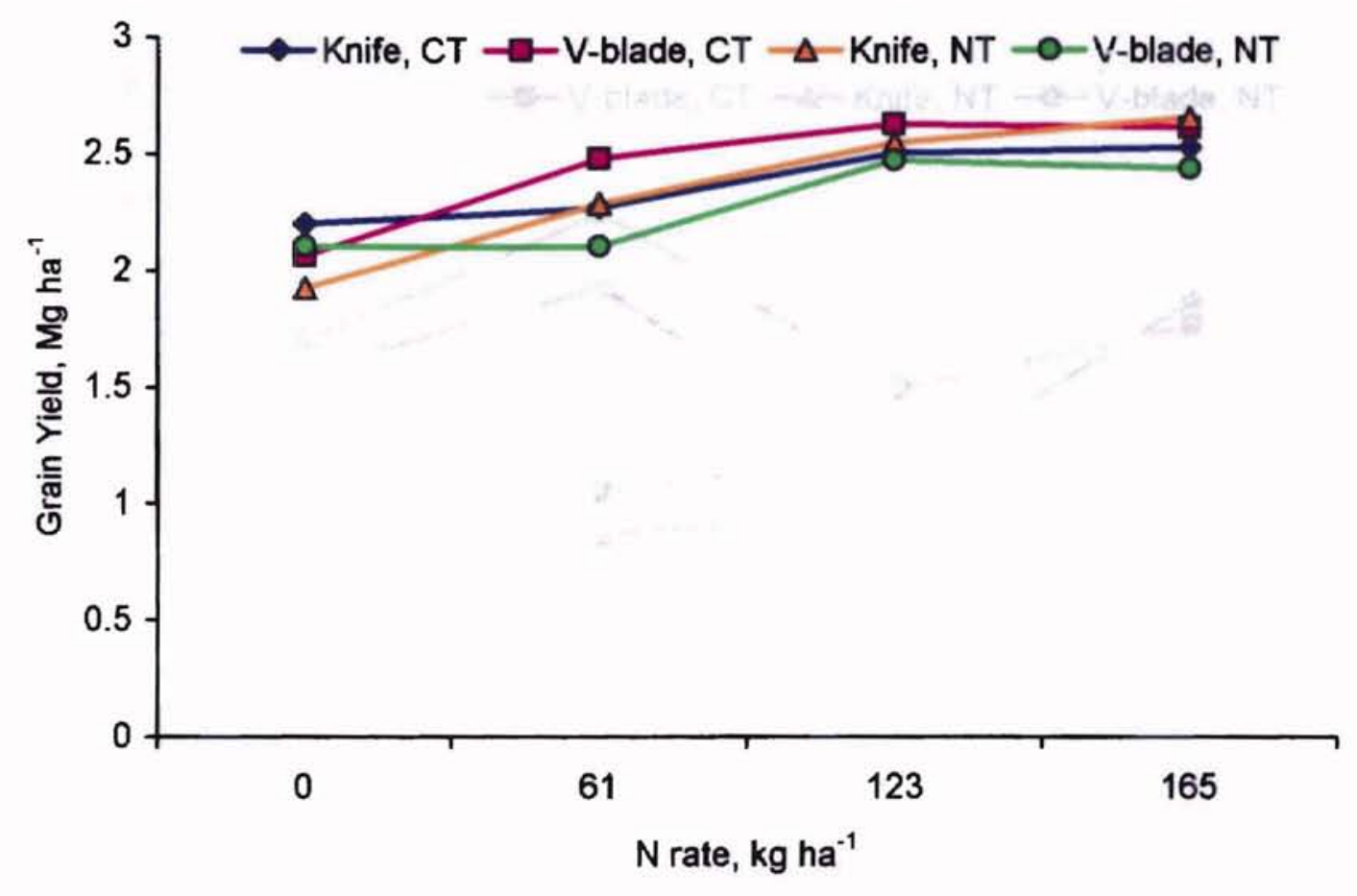


Figure 8. Effect of $\mathrm{N}$ rate, $\mathrm{N}$ method, and tillage on grain yield at Lahoma, $\mathrm{OK}$, 2001.

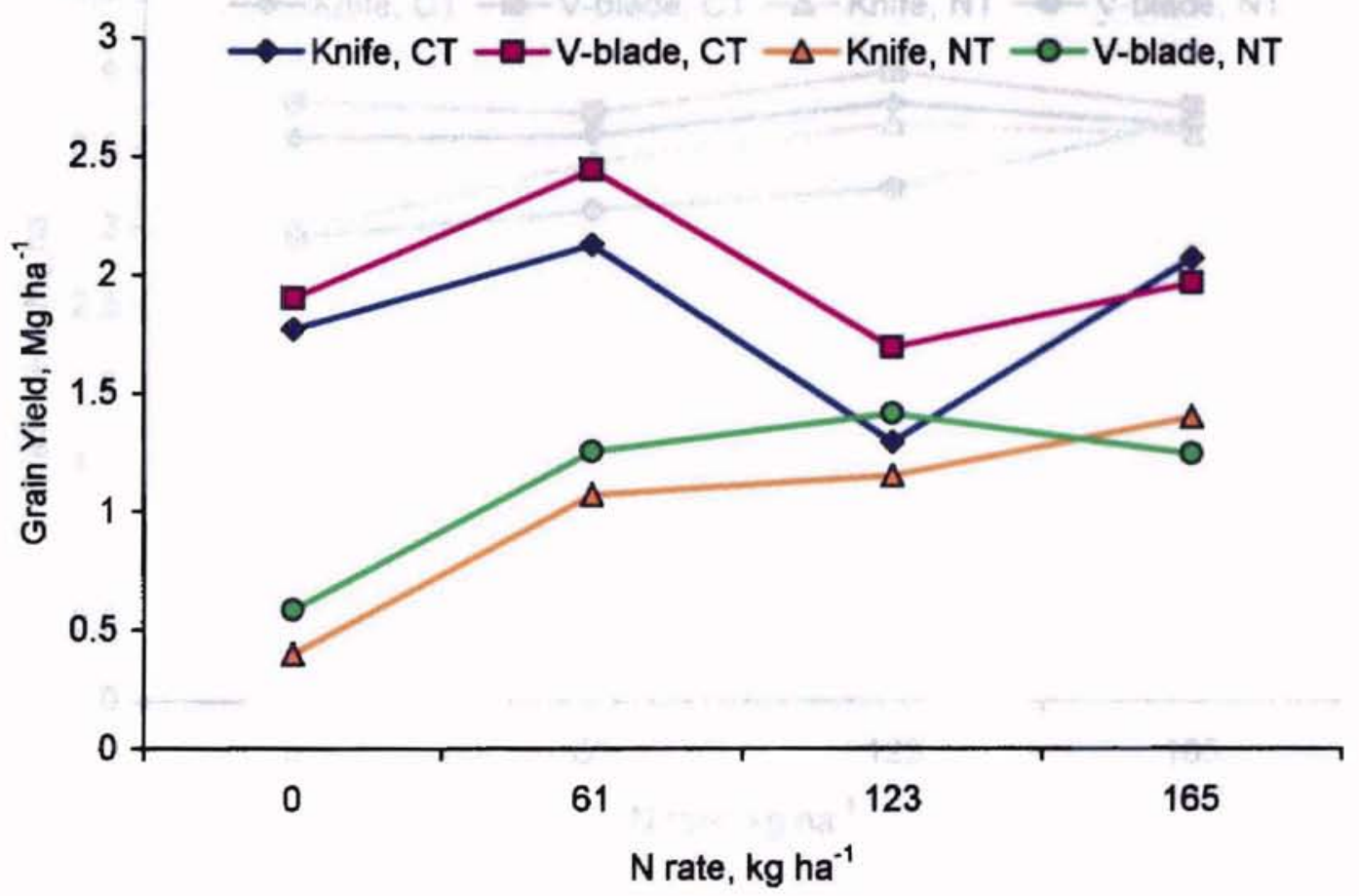


Figure 9. Effect of $\mathrm{N}$ rate, $\mathrm{N}$ method, and tillage on grain yield at Efaw, OK, 2002.

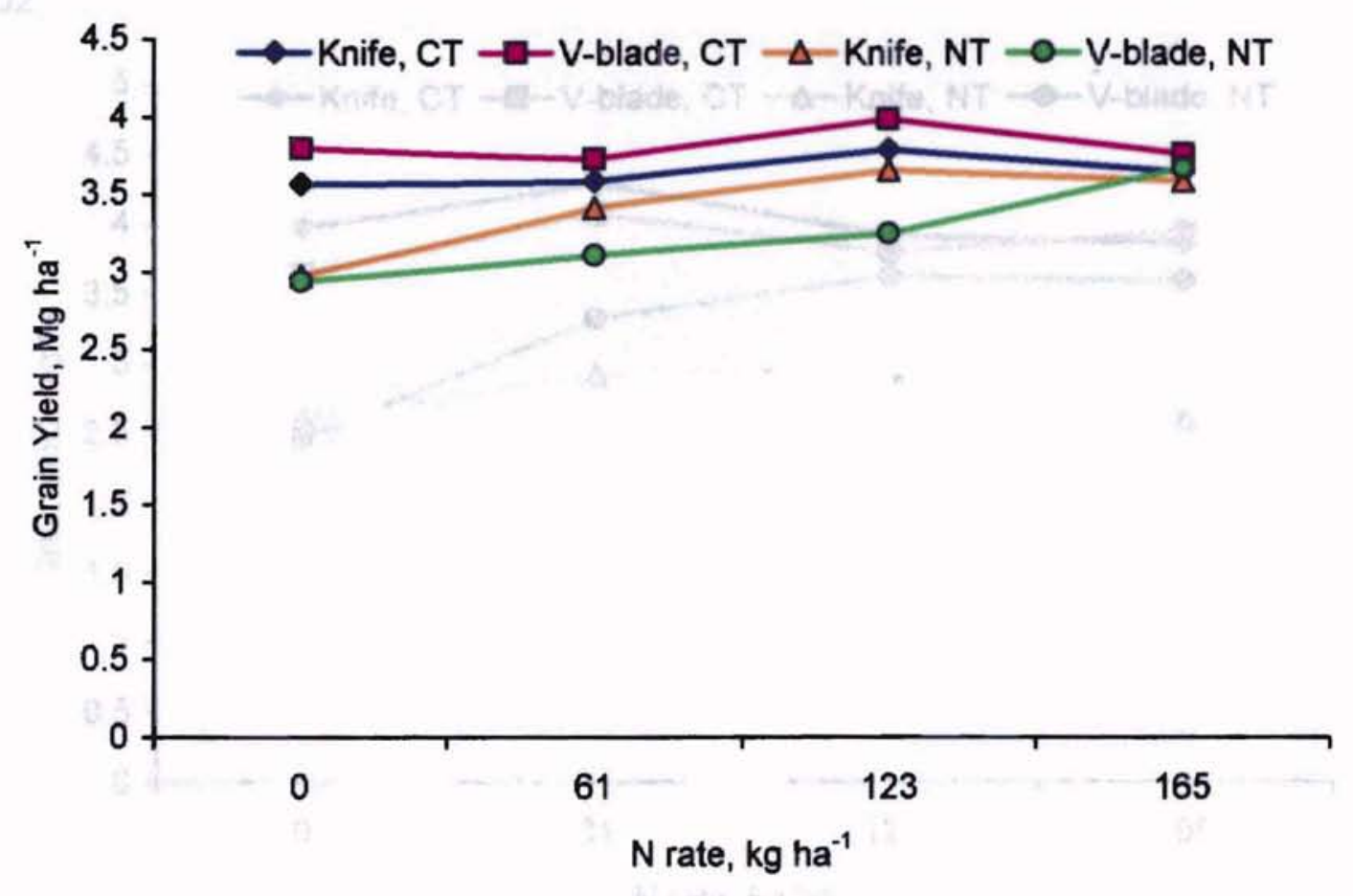


Figure 10. Effect of $\mathbf{N}$ rate, $\mathbf{N}$ method, and tillage on grain yield at Lahoma, $\mathrm{OK}$, 2002.

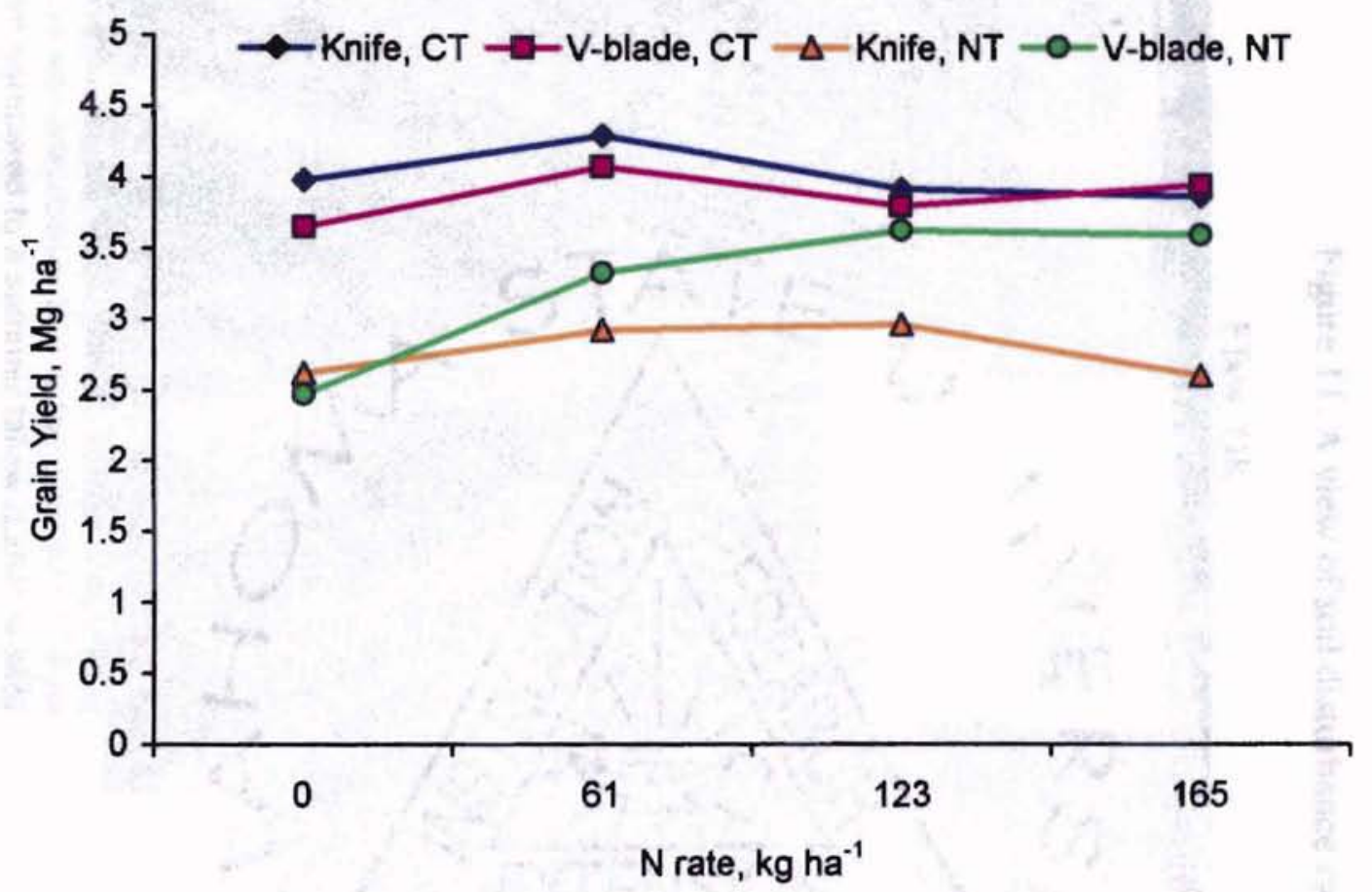


Figure 12. Figure 11. A view of soil disturbance caused by AA V-blade application in no-till at 2002

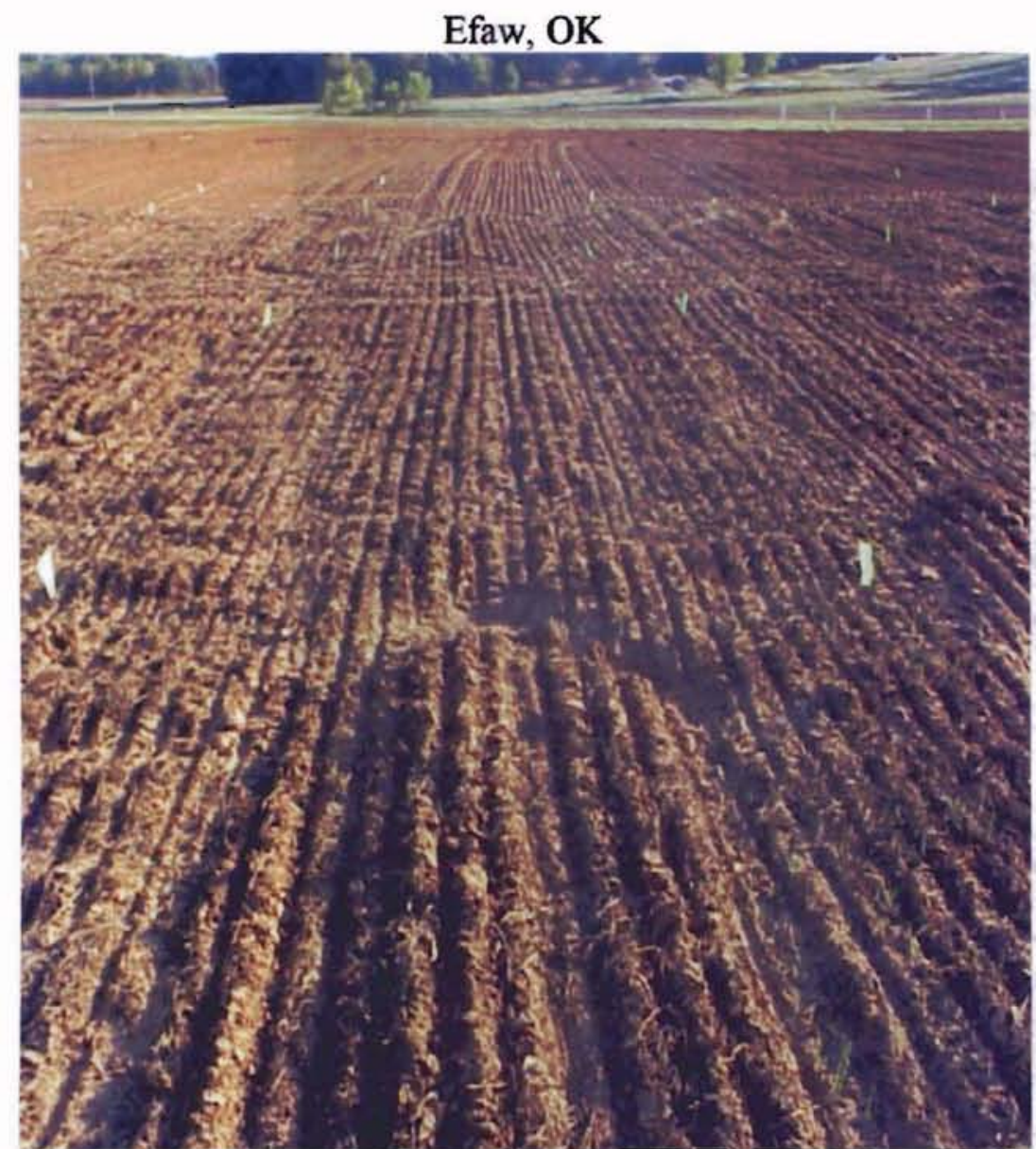

* Note less soil disturbance due to the utilization of a summer cover crop when compared to a summer fallow (Lahoma site).
Lahoma, OK

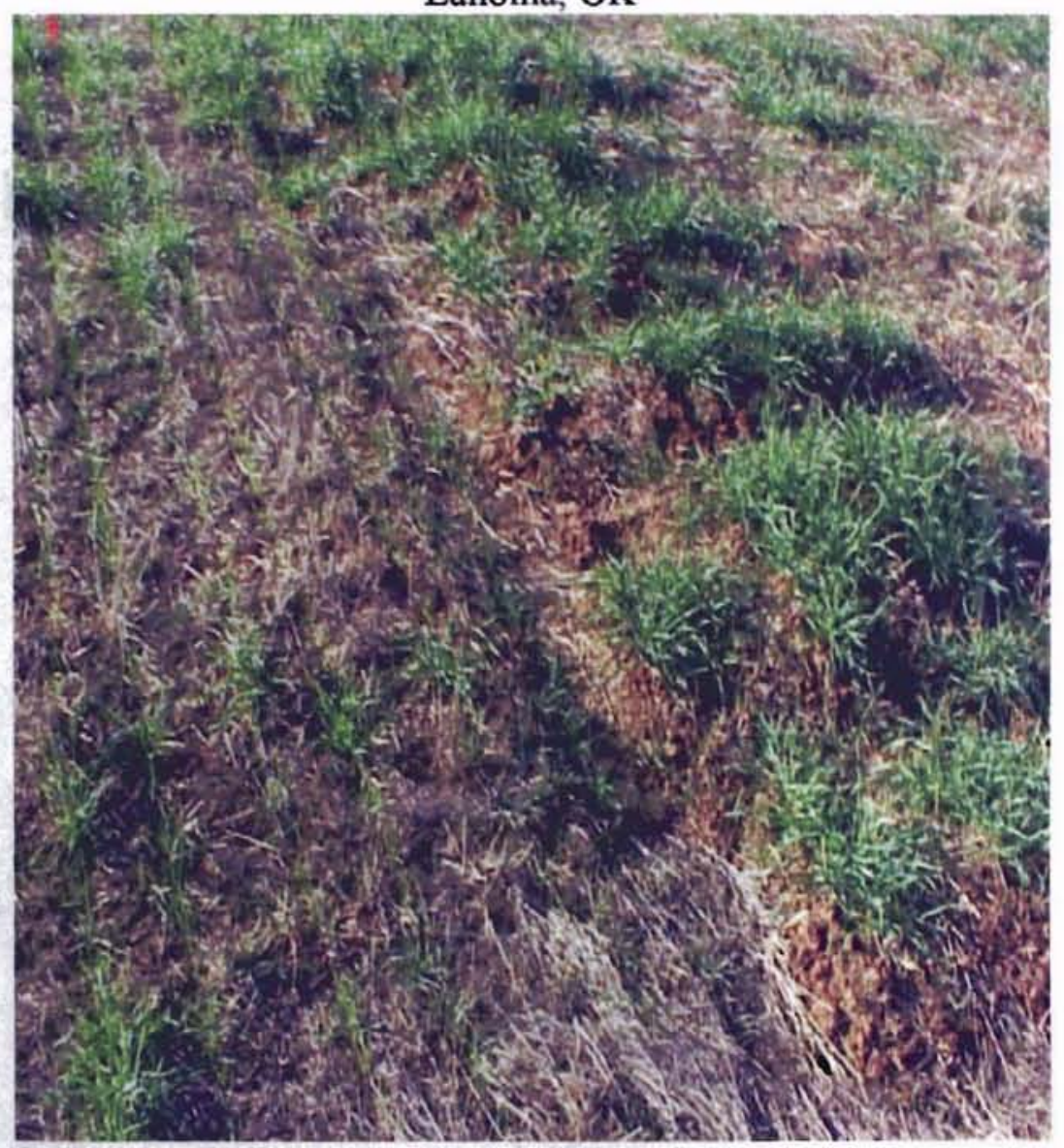

*Note the knife application on the left and the V-blade application on the right of this photograph. 
Figure 12. A view of emergence and seedbed differences caused by AA application in no-till at Lahoma, OK, 2002

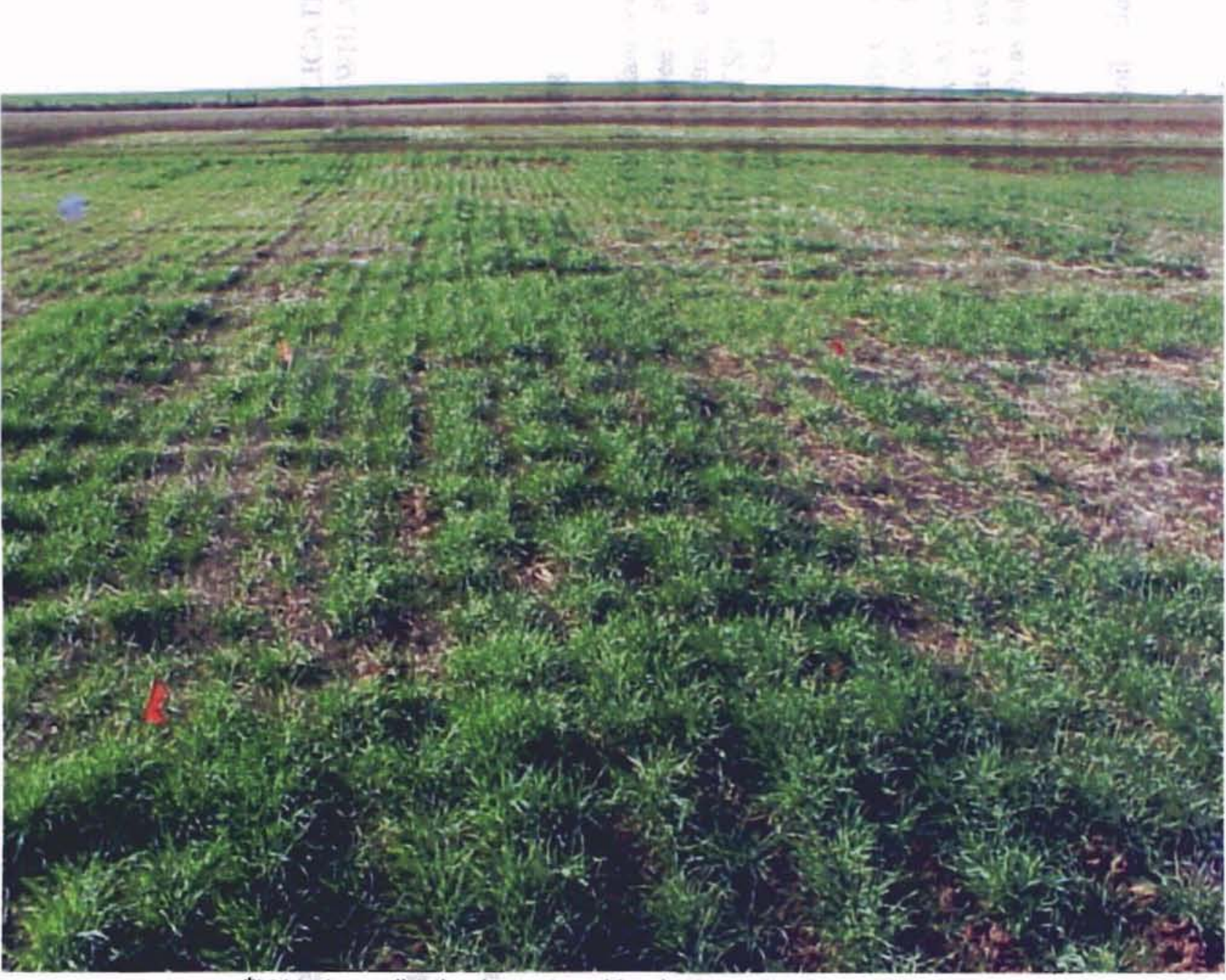

*V-blade application in center with a knife application on the right. 


\author{
VITA 2 \\ Roger Keith Teal \\ Candidate for the Degree of \\ Master of Science
}

Thesis: EFFECT OF TILLAGE AND ANHYDROUS AMMONIA APPLICATION ON NITROGEN USE EFFICIENCY OF HARD RED WINTER WHEAT

Major Field: Plant and Soil Sciences

Biographical:

Personal Data: Born in Manchester, Tennessee, on August 15, 1978.

Education: Graduated from Coffee County Central High School, Manchester, Tennessee in May 1996; received Bachelors of Science degree in Plant and Soil Science from University of Tennessee-Martin, Martin, Tennessee in May 2000. Completed the requirements for the Master of Science degree with a major in Plant and Soil Sciences at Oklahoma State University in August 2002.

Experience: farm employee for Pine Grove Dairy, 1991-2000, Shady Grove, Tennessee; assistant manager for Maple Creek Dairy, 1991-2000, Mud Creek, Tennessee; lab instructor for University of Tennessee-Martin, 1998-2000, Martin, Tennessee; employed by Oklahoma State University, Department of Plant and Soil Sciences as a graduate research assistant, 2000-2002.

Professional Memberships: American Society of Agronomy and Soil Science Society of America. 